\title{
Liselerde Görev Yapan Yönetici ve Öğretmenlerin, EBA Akademik Destek Platformu Hakkındaki Görüşleri (Erzincan İli Örneği)
}

\author{
Opinions of Educational Principals and Teachers Working at High Schools about the \\ EBA Academic Support Platform (Erzincan Province Example)
}

\author{
Hakan İBİİi ${ }^{1}$, Doç. Dr. Sinan YALÇIN ${ }^{(D)} 2$
}

\begin{abstract}
$\ddot{O} z$
Pandemi döneminde tüm dünyada olduğu gibi Türkiye'de de yüz yüze eğitim-öğretim aksamış, bu sebeple gelişen teknolojiler hayatımızın her alanında olduğu gibi eğitim alanında da büyük önem kazanmıştır. Bundan dolayı başarılı bir eğitim-öğretim dönemi geçirmek için yapay zekâ teknolojileri eğitim teknolojilerine entegre edilmiştir. Bu kapsamda EBA Akademik Destek Platformu hizmete sunulmuştur. Lise 11. ve 12. sınıf öğrencilerine yönelik olan platform, üniversite sınavına yönelik eğitim içerikleri ve hedefler sunarak kullanıcılarına rehberlik etmektedir. Bu araştırmanın amacı, 2019-2020 eğitim-öğretim yılının ikinci döneminde faaliyete giren EBA Akademik Destek Platformu'na ilişkin ortaöğretimde görev yapan okul yöneticilerinin ve öğretmenlerin görüşlerinin incelenmesidir. Araştırma yöntemi olarak nitel araştırma yöntemlerinden "olgu bilim deseni" kullanılmıştır. Araştırmanın çalışma grubunu, Erzincan il merkezinde görev yapan 10 okul yöneticisi ve 20 öğretmen oluşturmaktadır. Veriler, araştırmacılar tarafından geliştirilen "yarı yapılandırılmış görüşme formu" ile toplanmıştır. Pandemi sürecinden dolayı ve katılımcıların da isteği üzerine, katılımcı görüşleri yazılı olarak ya da online form kullanılarak alınmıştır. Elde edilen veriler içerik analizine tabi tutulmuştur. Araştırma sonucunda katılımcıların, platform arayüzünü sade ve kullanışlı buldukları görülmüştür. Platformun kullanılması ile okul ve ders bazlı hedef ve stratejilerde bir değişiklik olmadığ verilerinin, öğretmenlerin performanslarını değerlendirirken kullanılmadığı fakat sonraki eğitim dönemlerinde kullanılabileceği tespit edilmiştir.
\end{abstract}

Anahtar Kelimeler: EBA Akademik destek, okul yöneticileri, ortaöğretim öğretmenleri

Makale Türü: Araştırma

\begin{abstract}
In Turkey, in just the same way with the World, face-to-face education has gone wrong during the pandemic, and so improving technology has gained greater importance in the field of education, as in every area of our lives. Therefore, artificial intelligence technologies have been integrated into educational technologies in order to have a successful education period. The EBA Academic Support Network has been put into action. The platform, serving for 11 th and 12 th grade students, guides its users by offering educational contents and goals for the university exam. The aim of this research is to examine the opinions of school principals and teachers working in secondary education regarding the EBA Academic Support platform, which started operating in the second semester of the 2019-2020 academic year. As the research method, phenomenology pattern, one of the qualitative research methods, was used. The study group of the research consists of 10 school principals and 20 teachers working in the city center of Erzincan. The data were collected through a semi-structured interview form developed by the researchers. Due to the pandemic process and at the request of the participants, the participant's opinions were taken in writing or using the online form. The data obtained were subjected to content analysis. As a result of the research, participants found the platform interface simple and useful. With the use of the platform, it was determined that there was no change in school and course-based goals and strategies. It
\end{abstract}

${ }^{1}$ İMKB Müşir Zeki Paşa Ortaokulu, hakanibili2004@gmail.com.

${ }^{2}$ Erzincan Binali Yıldırım Üniversitesi, Eğitim Fakültesi, syalcin@erzincan.edu.tr.

Atıf için (to cite): İbili, H. ve Yalçın, S. (2021). Liselerde görev yapan yönetici ve öğretmenlerin, EBA Akademik Destek Platformu hakkındaki görüşleri (Erzincan ili örneği). Afyon Kocatepe Üniversitesi Sosyal Bilimler Dergisi, 23(2), 462-487. 
has been determined that the teacher data on the platform are not used while evaluating teachers' performances, but can be used in the following education periods.

Keywords: EBA academic support, school principals, secondary school teachers

Paper Type: Research

\section{Giriş}

Geçmişten günümüze teknolojinin gelişmesi ile birlikte insan hayatının da değiştiği görülmektedir. Teknolojide yaşanan gelişmelerle birlikte hayatın her alanında olduğu gibi eğitim alanında da değişimler kendini göstermiştir. Bu bağlamda dünyadaki birçok ülke, bilgi iletişim teknolojilerini merkeze alan projeler geliştirip uygulayarak bu hızlı değişime ayak uydurmuştur (Coşkunserçe ve İş̧̧itürk, 2019, s. 261). Ülkeler için önemli olan eğitimin gelişen teknolojiler 1şığında, çağın koşullarına uyan, gelecekteki gereksinimleri karşılayan, bu doğrultuda gelişmeyi ve değişebilmeyi sağlayabilecek olmasıdır. Bu dönüşüm ve gelişim sürecinde yüz yüze, uzaktan, çevrim içi ve çevrim dışı gibi eğitimin bütün ögeleri bir arada kullanılmalıdır (Özen, 2019, s. 7). Teknolojinin eğitimde kullanılması, çoklu zekâya uygun etkinliklerin sağlanması ve birçok duyuları kapsayan öğrenme etkinliklerine yer verilmesi bakımından önemli sayılabilecek bir konudur (Saklan ve Ünal, 2018, s. 497).

Tüm dünya ülkelerinin eğitim alanında değişmesine ve gelişmesine neden olan teknolojik gelişmeler ülkemizde de kendini göstermiş; İntel Öğretmen Eğitimi, Uzaktan Öğretmen Eğitimi, İntel Öğrenci Programı ve Fırsatları Artırma ve Teknolojiyi İyileştirme Hareketi (FATIH) gibi eğitim alanında birçok proje geliştirilmiştir. Bu projeler arasında öne çıkan ve günümüzde devam eden proje, FATİH Projesidir. FATİH Projesi; geliştirilen eğitim politikaları, güncellenen stratejik planlardaki hedefler doğrultusunda ve "Vizyon 2023" kapsamında yürütülmektedir (Coşkunserçe ve İşçitürk, 2019, s. 261). Tüm dünyada olduğu gibi Türkiye'de de eğitim alanında geliştirilen bu tarz projeler, pandemi koşullarında yüz yüze eğitime ara verilmesi sonucunda uzaktan eğitime geçilmesinde ve başarıla yürütülmesinde aktif rol oynamıştır.

\section{Literatür Taraması}

\subsection{Uzaktan Eğitim}

Yaşanan salgın sürecinden dolayı eğitim kurumlarında yüz yüze eğitimlere ara verilerek uzaktan eğitim sürecine geçilmiştir. Yüz yüze eğitimin durması sonucu dünyada tüm eğitim kademelerinde öğrenim gören öğrenci nüfusunun yaklaşık 1,7 milyarı bu süreçten olumsuz etkilenmiştir (UNESCO, 2021). Yaşanan olumsuzlukların önüne geçmek amacıyla gelişen teknolojilerin eğitim-öğretim sürecine entegre edilmesiyle oluşan ve sürekli gelişen uygulamalardan biri de uzaktan eğitim uygulamalarıdır. Uşun (2006) uzaktan eğitimi; eğitimöğretim sürecinin büyük bir kısmında öğretmen ve öğrencinin farklı ortamlarda olduğu, öğrenciye bireysellik ve esneklik tanıyan, öğrencinin tüm duyularına hitap eden materyallerin yer aldığ 1 , bilgi ve iletişim teknolojilerinin kullanılarak geliştirilen sistemli bir eğitim uygulaması, şeklinde tanımlamaktadır. Kısacası uzaktan eğitim; teknolojik alt yapı ve ekonomik koşullar çerçevesinde, televizyon, basılı araçlar, radyo ve internet kullanılarak senkron ya da asenkron gerçekleştirilen eğitim uygulamasıdır. Dünyada uzaktan eğitim uygulaması ilk olarak 1782 yılında ABD'de, "Steno Dersleri” şeklinde karşımıza çıkmaktadır. ABD'de, uzaktan eğitim uygulamaları ticari girişimlerin de artmasıyla sürekli gelişmiş ve bu konuda dünya ülkelerine rehberlik ve önderlik yapmıştır (Akyürek, 2020, s. 5). Uzaktan eğitimdeki gelişmeleri en yakından takip eden ülkeler, Avrupa ülkeleri olmuştur. Türkiye'de ise ilk kez 1960 yılında "Mektupla Öğretim Merkezi" adıyla bir kurul kurulmuş (Özarslan ve Ozan, 2014, s. 85) ve 1962 yılında mektupla öğretim başlatılarak 1968 yılında da televizyon aracılığıyla eğitsel yayınlar yapılmıştır. 
Sürekli gelişen uzaktan eğitim uygulamaları, günümüzde kurs yönetim sistemleri(CMS) ve öğrenim yönetim sistemleri(LMS) şeklinde karşımıza çıkmaktadır. Bu sistemler kapsamında dünyada en yaygın kullanılan araçlar ise: Google Classroom, Microsoft Teams, Zoom, Google Meet Hangouts, Moodle, Edmodo, Blackboard, Sakai, Lams gibi uygulamalar şeklinde karşımıza çıkmaktadır (Bergdahl ve Nouri, 2020, s. 8; Jacobs ve Ivone, 2020, s. 4; Romero Martínez, Ordóñez Camacho, Guillén-Gamez ve Bravo Agapito, 2020, s. 60). Bu uygulamaların birçoğu birçok dünya ülkesinde(ABD, Türkiye, İngiltere, Avusturalya, Hollanda gibi) aktif olarak kullanılmaktadır. $\mathrm{Bu}$ uygulamaların dışında kendi geliştirdikleri uygulama ve platformları kullanan ülkeler de bulunmaktadır. Bu uygulamalar arasında sürekli geliştirilen ve aktif olarak kullanılan uygulamalar: Cned: Sinıfim evde (Fransa), UNIBO platformu (Italya), Açık Eğitim Kaynakları Kütüphanesi (OER) (Finlandiya) (OECD, 2020), Ev Tabanlı Öğrenme [Home Based Learning (HBL)] (Singapur), Rain Classroom Öğretim Platformu (Çin), EBA, EBA Akademik Destek Platformu (Türkiye)'dur (Sözen, 2020, s. 305-312). Bu uygulamaların ortak özelliği, öğrencilere ve öğretmenlere senkron ve asenkron eğitim-öğretim yapmalarını sağlamaktır. Bu uygulamalarda; ders videoları, sınavlar, sorular, sunumlar ve ders kitapları gibi materyaller bulunmaktadır.

Uzaktan eğitim sürecinde dünya ülkeleri canlı dersler yapmak için sykpe, zoom ve Google classroom gibi uygulamaları aktif kullanmaktadırlar. Türkiye'de canlı dersler belirli bir süre EBA alt yapısı kullanılarak yapılmış, salgın sürecinin ağırlaşmasından dolayı ve kullanım oranın aşırı yükselmesi sonucunda Aralık 2020 tarihinden itibaren sykpe, zoom ve Google clasroom gibi uygulamalar kullanılmaya başlanmıştır. Ayrıca MEB tarafından Uzaktan Eğitim Merkezi(UZEM) kurularak (Özbay, 2015, s. 387) uzaktan eğitim süreci aktif olarak takip edilmiş ve süreçte yaşanan aksaklıkların giderilmesi için hızlı bir şekilde planlar yapılarak uygulamalar geliştirilmiştir.

\subsection{FATİH Projesi}

Günümüzde eğitimin; bireyselleştirilmiş, iş birliğine dayalı, proje tabanlı, informal, yetenek temelli, esnek, interaktif ortamları destekler olması ve teknolojik araçlarla okul dışında da desteklenmesi gerekmektedir (Memişoğlu ve Tapan-Broutin, 2018, s. 138). FATİH Projesi, eğitim-öğretimde anayasal hak olan firsat eşitliğini sağlamak ve okullarda kullanılan teknolojik alt yapıyı iyileştirmek amacıyla bilişim teknolojileri araçlarının daha fazla duyu organına hitap edilecek şekilde, derslerde etkin kullanım için başlatılmıştır (MEB, 2020b). FATİH Projesi oluşturulurken 5 temel ölçüt baz alınmıştır. Bu ölçütler (MEB, 2020b): Her an, her yerden; zaman, mekân ve araçlardan bağımsız olarak hizmet sunabilmek (Erişilebilirlik). Hedef bazlı, daha verimli çalışma ortamları ve gelişim alanları sunabilmek (Verimlilik). Tüm paydaşların en iyi hizmete erişebilmesini sağlayabilmek (Fırsat Eşitliği). Gelişimin doğru değerlendirilebilmesi için sürecin ve sonuçların doğru ölçülebilmesini sağlamak ve buna göre geri bildirim verebilmek (Ölçülebilirlik). Tüm eğitimin kalitesini ölçülebilir şekilde yükseltebilmek (Kalite).

FATİH Projesi, çok yönlü bir proje olmasına rağmen proje ile ilgili yapılan araştırmalarda genelde projenin donanım boyutunun incelendiği görülmektedir (Altı ve Kalelioğlu, 2015, s. 91). Yukarıda belirtilen ölçütler doğrultusunda geliştirilen FATİH Projesi sadece donanımsal bir proje olarak görülmemelidir. FATIH Projesi, günümüz teknolojileri doğrultusunda geliştirilmiş ve geliştirilmeye devam eden geniş çaplı bir projedir. Bu proje 5 ana bileşenden oluşmaktadır. Bu bileşenler (MEB, 2020b): Donanım ve yazılım alt yapısını sağlamak. Eğitsel e-içeriğin sağlanması ve yönetilmesi için gerekli adımları atmak. Bilinçli, güvenli, yönetilebilir ve ölçülebilir BT (Bilişim Teknolojileri) kullanımını sağlamak. Öğretim programlarında etkin BT kullanımını entegre etmek. Öğretmenlere yönelik hizmet içi eğitimler vermek.

Yukarıda belirtilen ana bileşenler kapsamında okullardaki donanımsal alt yapının sağlanması, derslere ait e-içeriklerin oluşturulması ve oluşturulan e-içeriklere ulaşılmasının sağlanması, öğretmenlerin projeye adaptasyonları için eğitimlere alınması sağlanmıştır. Bu 
proje ile eğitimde 21. yüzyıl becerilerinden olan teknoloji kullanımı; problem çözme, etkili iletişim, birlikte çalışma, analitik düşünme ve iş birliği gibi beceriler geliştirilerek öğrencilerimiz pasif olmaktan çıkarak aktif katılım gösterecek ve eğitimde fırsat eşitliği ilkesi geliştirilecektir (MEB, 2020b). Bu proje kapsamında tüm okullarını teknoloji ile donatan Milli Eğitim Bakanlığı, eğitimdeki firsat eşitliğini tam anlamıyla gerçekleştirmek ve okullardaki teknolojinin daha aktif kullanılmasını sağlamak için e-içerik (Eğitim Bilişim Ağı) platformunu geliştirmiştir. Böylelikle eğitim ortamında sorun olarak görülen birçok problem çözülmüş, sınıf ortamında ve sınıf dışında sanal materyaller kullanılarak ders içeriklerinin öğrenciler tarafından kolay öğrenilmesi ve öğrenilenlerin pekiştirilmesi sağlanmıştır (Yılmaz, 2020, s. 72).

\subsection{Eğitim Bilişim Ağı (EBA)}

EBA, FATİH Projesinin e-içerik ayağı olarak 2012 yılında Yenilik ve Eğitim Teknolojileri Genel Müdürlüğü (YEĞİTEK) tarafindan geliştirilmiştir. EBA, internet tabanlı online bir sosyal eğitim platformudur (MEB, 2020a). EBA'nın temel amac1, ihtiyaç duyulan her an ve her yerde bilişim teknolojilerini kullanarak her sınıf seviyesinde etkili ve kaliteli materyal kullanımını desteklemektir (MEB, 2020a). Bu amaç doğrultusunda EBA; simülasyon, video, animasyon, e-kitap, etkileşimli ve bireysel öğrenme materyalleri gibi içeriklerden oluşturulmuştur. Öğretmenler, öğrenciler ve yöneticiler olmak üzere eğitim-öğretimde yer alan tüm paydaşları için tasarlanan EBA'nın hedefleri şöyledir:

Kullanıcılara farklı, zengin, eğitici ve kaliteli içerikler sunmak. Bilişim teknolojileri kültürünü yaygınlaştırarak eğitim-öğretimde aktif kullanılmasını sağlamak. İçerik ihtiyacına cevap vermek. Kullanıcıların aktif olarak bilgi alışverişinde bulunabilmelerini sağlamak. Her geçen gün büyüyen arşiviyle derslere katkı sağlamak. Bilgiyi öğrenirken aynı anda bilgiyi yeniden yapılandırarak yeni bilgi üretilmesini sağlamak. Farklı öğrenme stillerine (sözel, görsel, sayisal vb.) sahip öğrencileri kapsamak. Bütün öğretmenleri ortak bir paydada buluşturarak eğitime el birliğiyle yön vermelerini sağlamak. Kısacası EBA, teknolojiyi bir amaç olarak değil bir araç olarak kullanmak amacıyla tasarlanan sosyal bir eğitim platformudur (MEB, 2020a).

FATIH Projesi kapsamında geliştirilen EBA; her sınıf seviyesine uygun, güvenilir, kaliteli, doğru ve kolay kullanılabilen e-içerikler sunmak için oluşturulan en ciddi eğitim hamlelerinden biri olarak düşünülebilir. EBA sayesinde sadece okulda değil okul dişında da eğitim devam etmektedir. (Saklan ve Ünal, 2018, s. 521). EBA'nın eğitimde kullanılmasıyla birlikte öğrencilerin eğitim sürecinde aktif rol alabilecekleri, kendi yöntemleri ve bireysel hızları ile öğrenen kişiler olabilecekleri düşünülmektedir (Özen, 2019, s. 7). Şahin ve Erman (2019) tarafından yapılan çalışmada da EBA'nın; konuları pekiştirme firsatı sunduğu, öğrencilerin sürece etkin ve aktif katılımına olanak sağladığı, ders içi etkinlikleri desteklediği, öğrenmeyi daha kolay ve kalıcı hale getirdiği görülmektedir. EBA, sergilediği bu özellikler ile dünyada kullanılan birçok uzaktan eğitim platformu (Cned: Sınıfım evde, UNIBO platformu, Ev Tabanlı Öğrenme, Rain Classroom Öğretim Platformu gibi) ile benzerlik göstermektedir.

Ayrıca Şahin ve Erman (2019), EBA platformunun başarıyı artırdığını, kullanım sırasında dönüt almaya imkân verdiğini ve bireyin kendisini değerlendirme becerisini geliştirdiğini yaptıkları çalışmada tespit etmiştir. Alanyazın taramasında, EBA'nın yapılan merkezi sınavlara yönelik içerik ve yönlendirme konusunda eksik ve yetersiz olduğu görülmektedir. Özellikle ortaöğretim öğrencilerinin iyi bir üniversitede iyi bir bölüme yerleşebilmeleri için AYT ve TYT sınavlarından başarılı olmaları gerekmektedir ve bundan dolayı öğrenciler kaliteli ders içeriklerine ihtiyaç duymaktadır (Bahçeci ve Efe, 2018, s. 679). Eğitim Bilişim Ağı bu alandaki açığı kapatmak için 2020 yılının birinci evresinde yapay zekâ teknolojisine sahip olan EBA Akademik Destek Platformu'nu kullanıcılarına sunmuştur.

\subsection{Yapay Zekâ}

Yapay sinir ağları ile insan beynine ait çalışma ilkelerinin taklit edilmesiyle oluşturulan bilgi işleme sistemlerine yapay zekâ denir. Bu sistem; akıl yürütme, insan gibi düşünme, 
öğrenme, anlamlandırma, yapılandırma, genelleme yapma ve daha önce edinilmiş deneyimlerden öğrenme gibi zihinsel olaylara ait görevleri yapabilme becerisinin bilgisayar ortamındaki benzetimidir (Akyürek, 2013, s. 22). Yakın zamanda olmasa dahi yapay zekânın, hayatın tüm alanlarını etkilemesi kaçınılmazdır. "Gelecekte yapay zekânın ne zaman insanların yaptığı çeşitli işleri yapabileceğine dair" adlı çalışma sonucunda elde edilen bulgulara göre, 2051 yılına kadar yapay zekânın tüm insan görevlerini otomatikleştirebileceği tespit edilmiştir (Öztuna, 2017, s. 99). Yapay zekâ çalışmaları, endüstri 4.0'ın hayatımıza girmesi ile hız kazanmıştır. Günümüzde yapılan yapay zekâ çalışmaları iki başlık altında toplanmıştır. Bunlar; yapay genel zekâ ve yapay dar zekâdır. Yapay genel zekâ, biyolojik olarak insan sinir sisteminden esinlenerek kendi kendine öğrenme sürecini sürdürebilen ve insan gibi davranabilmesi hedeflenen sistemdir. Yapay dar zekâ ise belirli bir problemin çözümü için geliştirilen ve kendisine gelen verilerden öğrenmeyi sağlayan sistemdir. $\mathrm{Bu}$ sistemde, öğrenmenin sürekli olabilmesi için veri girişinin sürekliliği gereklidir (Aslan, 2019, s. 16). Eğitim sisteminde kullanılan yapay zekâ sistemlerinin, yapay dar zekâ sistemi baz alınarak geliştirildiği söylenebilir. Çünkü eğitimde kullanılan yapay zekâ sistemleri, öğreten ve öğrenen sistemi kullandıkça yani veri aktardıkça kendini geliştirmeyi sürdüren sistemlerdir. Yapılan alanyazında, eğitim sistemlerinde en çok kullanılan 2 tür yapay zekâ sisteminin olduğu görülmektedir. Bu sistemler, akıllı öğretim ve akıllı eğitmenlik sistemleridir.

Akıllı Eğitmenlik Sistemleri (AES): Aktif katılım gerektiren öğrenme ortamlarında insan temelli öğrenmeyi destekleyen; kime, neyi ve nasıl öğreteceğini bilen ve yapay zekâ tekniklerinden faydalanılarak dizayn edilmiş bir pedagojik bilgisayar sistemidir (Esdeira, 2017, s. 12). AES'i diğer eğitim teknolojilerinden ayıran unsurlar şunlardır (Noe, 2009, s. 265): Eğitim ile eğitilenlerin bireysel ihtiyaçlarını eşleştirebilir, eğitilen ile iletişim kurup cevap verebilir, eğitilenin öğrenme sürecini modelleyebilir ve eğitilenin önceki performanslarına göre hangi bilgiyi sunacağına karar verebilir, eğitilenin anlama seviyesine yönelik kararlar alarak onu yönlendirebilir ve kendi eğitim sürecine ilişkin sonuçlandırma kararları alabilir.

Akıllı Öğretim Sistemleri, yapay zekâ teknolojileri kullanılarak öğretim amaçlı geliştirilen bilgisayar sistemleridir (Sleeman ve Brown, 1982, s. 4). Ak1llı Öğretim Sistemleri'nin en önemli özelliği, bireysel olarak öğrencinin öğrenme stiline göre yanıt verebilmesi ve onun için özelleştirilmiş öğretim içeriği sunabilmesidir (Kayabaş, 2010, s. 33).

Türkiye'de eğitim-öğretim kapsamında, akıllı eğitmenlik ve akı1lı öğretim sistemlerinin bir arada bulunduğu ve böylece eğitim sürecinde öğrenciye hem rehberlik yapan hem de öğrencinin seviyesine göre içerik hazırlayan EBA Akademik Destek Platformu geliştirilmişstir. Devlet eliyle geliştirilen bir platform olan EBA Akademik Destek Platformu, barındırdığ 1 bu özellikler ile dünyadaki birçok yapay zekâya sahip olan eğitim sisteminin önüne geçmektedir. Aynı zamanda bu özellikleri sayesinde, dünyadaki devlet eliyle geliştirilen eğitim platformlarına rehberlik etmektedir. Çünkü devlet eliyle geliştirilen eğitim platformları kullanıcılara sadece içerikler sunmakta ve dönütler vermektedir fakat rehberlik yapmamaktadır.

\subsection{EBA Akademik Destek Platformu}

EBA Akademik Destek Platformu, 11. ve 12. sınıfta okuyan öğrenciler ile liselerde görev yapan öğretmenlerin kullanımı için geliştirilen ve öğrencilerin belirledikleri hedefe eğitim-öğretim süresi içinde ulaşabilmeleri için kişiye özel çalışma programı geliştirebilen bir platformdur (YEĞİTEK, 2020). EBA Akademik Destek Platformu, kullandığı yapay zekâ sistemi sayesinde, öğrencilerin kendilerini hedeflerine götüren ve bireyselleştirilmiş yol haritasıyla çalışmalarına olanak sağlayan bir platformdur. $\mathrm{Bu}$ platformda, öğrencilerin performansları yapay zekâ sistemi tarafindan sürekli takip edilmekte ve öğrencilerin eksik oldukları konular hemen tespit edilerek kullanılan akıllı algoritmalar sayesinde öğrencilere özel, eksik giderme listeleri ve içerikler önerilebilmektedir (YEĞİTEK, 2020). EBA Akademik Destek Platformu'nu kullanmaya başlayan bir öğrencinin öncelikle hedef belirlemesi isteniyor. Süreç içerisinde kullandığı yapay zekâ teknolojisi ile öğrenciye hedefi hakkında dönütler veren 
platform, gerekirse hedef değiştirmesi için de yönlendirmelerde bulunabiliyor (EBA, 2020). Öğrenci, platforma ilk defa giriş yaptığında yapay zekâ sistemi tarafindan sunulan hazır bulunuşluk testi ile karşılaşmaktadır. EBA Akademik Destek Platformu, hazır bulunuşluk testi sonucunda öğrenciye mevcut durumu hakkında bilgi vererek haftalık ders programı planlamaktadır. Eğitim sürecinde öğrencilere 250.000'den fazla soru sunan EBA Akademik Destek Platformu, çözülen sorular ve deneme sınavı sonuçlarında öğrencilere; yeniden başla, eksiklerini gider ve çok soru çöz gibi dönütler vermektedir. Sistem tarafından yapılan dönütler, çözülen her testin ya da deneme sınavının çözümünden sonra verilmektedir. Böylece öğrenci konu bazlı eksiklerini hemen görebilmekte ve üzerinden zaman geçmeden eksiklerini telafi edebilmektedir.

EBA Akademik Destek Platformu, 4 farklı ara yüzden oluşmaktadır. Bunlar; öğretmen, yönetici, veli ve öğrenci arayüzleridir. Öğretmen ve öğrenci arayüzünde; "Takvim", "Testler”, "Raporlar" ve "Etütler" bölümü bulunmaktadır. Ayrıca, öğretmen arayüzünde öğretmenlerin öğrencilere çalışmalar gönderebileceği "Ödevler" sekmesi ve öğrencilerini yakından takip edebilmeleri için "Öğrenci Alanları Sekmesi” bulunmaktadır. Öğretmen arayüzünü kullanarak konuya ait video, içerik ve soruları ödev olarak öğrenciye gönderebilmekte ve öğrencinin konuya özgü seviyesini tespit edebilmektedir. Öğretmen ayrıca, öğrencilerin mevcut seviyelerini sınıf, ders ve konu bazında görebilmektedir. Böylece öğretmen, öğrenci ya da sınıf bazlı konuları tekrar edebilir ya da içerik ve soru ile öğrenciyi ödevlendirerek eksiklerini gidermesini sağlayabilmektedir. Yönetici arayüzünde; "Raporlar", "Etütler" ve "Ödevler" bölümü bulunmaktadır. $\mathrm{Bu}$ arayüz sayesinde yöneticiler, sürece hâkim olmakla beraber öğretmenleri ve öğrencileri bireysel anlamda da takip edebilmektedir. Böylece okul yöneticileri, elde ettikleri veriler doğrultusunda eğitim-öğretime yönelik farklı çalışmalar planlayarak uygulayabilirler. Ayrıca okul yöneticisi, kendi arayüzünden istediği öğretmenin arayüzüne geçiş yaparak öğretmen arayüzünü kullanabilmektedir.

Veli ise kullanacağ 1 arayüzde; çocuğunun hedef listesini, hedefi ile ilgili mevcut durumunu, derslerdeki mevcut başarı durumunu, gönderilen ders bazlı ödevleri ve öğretmen mesajlarını, ders bazlı çözülen soru miktarını, yapılan ders bazlı etütleri ve deneme sınavı sonuçlarını takip edebilmektedir.

EBA Akademik Destek Platformu sayesinde 21. yüzyılın teknolojisi olan yapay zekâ, eğitim sürecine başarılı bir şekilde dahil edilmiştir. Böylelikle EBA Akademik Destek Platformu; yönetici ve öğretmene, öğrencinin takibinde, eğitim hedeflerine ulaşmasında ve eğitim-öğretim sürecinde destek olurken aynı zamanda öğrenciye sistemli bir şekilde rehberlik yapabilmektedir. EBA Akademik Destek Platformu, öğrencilere sunmuş olduğu aktif rehberlik uygulaması ve aynı zamanda eğitimde yer alan tüm paydaşlara sunduğu hizmet sayesinde dünyada kullanılan özel ve devlete ait uzaktan eğitim uygulamaları arasından (Cned: Sınıfım evde, UNIBO platformu, Ev Tabanlı Öğrenme, Rain Classroom Öğretim Platformu gibi) bir adım öne çıkmaktadır.

Yapılan literatür taramasında EBA ile ilgili birçok çalışma yapıldığı görülmüş fakat EBA Akademik Destek Platformu ile ilgili herhangi bir çalışmaya rastlanmamıştır. Alanyazı taramasında, 2020 yılının ilk döneminde faaliyete giren EBA Akademik Destek Platformu ile ilgili görüşlerin araştırılmasına ihtiyaç olduğu görülmektedir. 11. ve 12. Sinıflara yönelik hizmet veren EBA Akademik Destek Platformu, 1.848.819 öğrenci ve 252.125 öğretmen tarafindan aktif bir şekilde kullanılmaktadır. Yüksek sayıda kullanıcıya aktif hizmet veren platform, yeni faaliyete giren her platform gibi kendini geliştirebilmesi ve daha verimli olabilmesi için kullanıcı görüşleri büyük önem arz etmektedir. Uzaktan eğitim sürecinde oldukça önemli olan bu platform ile ilgili olumlu ve olumsuz görüşlerin belirlenmesi sonucu, platformun güçlü ve zayıf yönleri tespit edilecektir. Ayrıca platformu kullanacak olan okul yöneticileri ve öğretmenlerin, teknolojik araçlar ve platform kullanımı ile ilgili eğitim alma durumları belirlenecektir. Yapılacak olan tespitler doğrultusunda önerilerde bulunulacaktır. Bu nedenle bu çalışma alan itibari ile önemli görülmektedir. 


\section{Araștırmanın Amacı ve Araștırma Soruları}

EBA Akademik Destek Platformu'nun hem içerik hem de kullanıcı arayüzünün geliştirilmesi ve eğitim sürecinde daha etkin kullanılabilmesi için, bu platformu aktif kullanan okul yöneticilerinin ve öğretmenlerin görüşleri oldukça önemlidir. Bu doğrultuda 2019-2020 eğitim-öğretim yılının ikinci döneminde faaliyete giren EBA Akademik Destek Platformu'na ilişkin ortaöğretimde görev yapan okul yöneticilerinin ve öğretmenlerin görüşlerinin incelenmesi amaçlanmıştır.

$\mathrm{Bu}$ amaç doğrultusunda yapılan araştırmada aşağıdaki sorulara cevap aranmıştır:

1. Okul yöneticilerinin ve öğretmenlerin, teknolojik araçları (bilgisayar, etkileşimli tahta gibi) kullanma yeterliliği hakkındaki düşünceleri nelerdir?

2. Okul yöneticilerine ve öğretmenlere platform ile ilgili bir eğitim verildi mi? Bu eğitimle ilgili okul yöneticilerinin ve öğretmenlerin görüşleri nelerdir?

3. Okul yöneticilerinin, öğretmenlerin EBA Akademik Destek Platformu'na yönelik algıları konusundaki görüşleri nelerdir?

4. Platformda yer alan yönetici ve öğretmen arayüzünün kullanışlılık durumu hakkındaki yönetici ve öğretmen görüşleri nelerdir?

5. Platformun eğitim-öğretim sürecinde aktif kullanılması ile okul yöneticilerinin, eğitimöğretime yönelik hedeflerinde ve stratejilerinde değişiklik olup olmadığına yönelik görüşleri nelerdir?

6. Platformun, öğretmenler tarafından eğitim-öğretim sürecinde aktif kullanılması ile birlikte öğretmenlerin ders bazındaki hedeflerinde değişiklik olup olmadığına yönelik görüşleri nelerdir?

7. Platformdaki öğretmenlere ait verilerin, öğretmen performansını değerlendirmede okul yöneticileri tarafından kullanılması hususunda okul yöneticilerinin görüşleri nelerdir?

8. Öğretmenlerin platformu kullanmalarından dolayı iş yüklerinde değişiklik olup olmadığına yönelik görüşleri nelerdir?

9. Öğretmenlerin platformda yer alan branşları ile ilgili içeriklerin, öğretim programında yer alan kazanımlarla uyumluluğu ve uygulanabilirliği hakkındaki öğretmenlerin görüşleri nelerdir?

10. Okul yöneticilerinin, EBA Akademik Destek Platformu'nun olumlu ya da olumsuz yönleri hakkındaki düşünceleri nelerdir?

11. Öğretmenlerin, EBA Akademik Destek Platformu'nun olumlu ya da olumsuz yönleri hakkındaki düşünceleri nelerdir?

\section{Araştırmanın Önemi}

Eğitim kurumlarının ve çalışanlarının, değişen teknolojilere ayak uydurmaları ve performanslarını arttıracak şekilde teknolojiyi kullanabilmeleri için kendilerini sürekli geliştirmeleri gerekmektedir. Çünkü gelişen teknolojileri takip etmeyen ya da edemeyen okul yöneticileri ve öğretmenler, mesleki anlamda yeterliliklerini zamanla yitirmeye başlayabilir. Ayrıca, eğitim sistemine yeni gelişen teknolojiler ne kadar entegre edilirse edilsin bu teknolojiyi kullanacak personel olmadığında eğitim sistemindeki yenilikler hiçbir anlam ifade etmeyebilir. Bu bağlamda EBA Akademik Destek Platformu'nun amacına ulaşması, liselerde görev yapan okul yöneticilerinin ve öğretmenlerin desteğiyle gerçekleşecektir. Ayrıca her platform gibi EBA Akademik Destek Platformu da gelişen ve değişen dünyada hem içerik hem de arayüz olarak kendisini sürekli geliştirmelidir. Platformun gelişimi, platformu kullanan kullanıcıların görüşleri doğrultusunda gerçekleşmektedir. Bu kapsam doğrultusunda bu çalışma EBA Akademik Destek 
Platformu ile ilgili ortaöğretimde görev yapan okul yöneticilerinin ve öğretmenlerin görüşlerini yansıtması açısından önemlidir.

\section{Yöntem}

\subsection{Araştırmanın Deseni}

$\mathrm{Bu}$ araştırmada, ortaöğretimde görev yapan okul yöneticilerinin ve öğretmenlerin, EBA Akademik Destek Platformu'na ilişkin görüşleri belirlenerek var olan durumu olduğu gibi ortaya çıkarmak hedeflenmiştir. $\mathrm{Bu}$ araştırmada verilerin toplanması, analizi ve yorumlanmasında nitel araştırma yönteminden faydalanılmıştır. Nitel yöntem, görüşme ve gözlem gibi metotlarla verilerin toplanıp, algı ve olayların doğal ortamlarında bütüncül ve gerçekçi bir biçimde ortaya konmasına olanak sağlamaktadır (Yıldırım ve Şimşek, 2008, s. 39). Fenomenoloji çalışmaları bireylerin zihinlerindeki örüntüleri, odak kavramları, kavram ve deneyimleri nasıl anlamlandırdıklarını ve aralarındaki ilişkileri inceler (Patton, 2005, s. 71). Veri toplama aracı olarak derinlemesine görüşme yöntemi veya yazılı olarak açık uçlu sorular kullanılabilir (Christensen, Johnson ve Turner, 2014, s. 52).

\subsection{Araştırmanın Özneleri}

Fenomenoloji çalışmalarında bilgi, özneler arası olarak üretilir. Bu bağlamda çalışmada özneler katılımcılar ve araştırmacılardır. Önce katılımcıların nitelikleri hakkında, daha sonra ise araştırmacıların nitelikleri ve çalışmada kendilerini nasıl konumlandırdıklarına ilişkin bilgi verilmiştir.

\subsubsection{Katılımcı Özellikleri}

Araştırmanın çalışma grubunu, 2019-2020 eğitim-öğretim yılında Erzincan ilinde MEB'e bağlı okullarda görev yapan 10 okul yöneticisi ve 20 öğretmen oluşturmaktadır. Çalışma grubunu belirlemede amaçlı örnekleme yöntemlerinden "maksimum çeşitlilik örneklemesi" tercih edilmiştir (Yıldırım ve Şimşek, 2008, s. 108-109). Maksimum çeşitlilik örneklemesi ile araştırmaya katılanların farklı demografik özelliklere sahip olmalarına dikkat edilmiştir (McMillan ve Schumacher, 2006, s. 331). Kat1lımcıların belirlenmesi sirasında; farklı türde okullarda görev yapıyor olmalarına, farklı sosyo-ekonomik bölgelerde bulunan okullarda görev yapıyor olmalarına, branşlarının, eğitim durumlarının ve hizmet sürelerinin farklı olmalarına dikkat edilmiştir. Böylelikle, araştırma sonucunda elde edilecek bulgular ve sonuçlar zengin olabilmektedir (Yıldırım ve Şimşek, 2006, s. 137). Çalışma grubunda yer alan katılımcılara ait özellikler Tablo 1'de verilmiştir.

Tablo 1.Kat1lımcıların özellikleri

\begin{tabular}{|c|c|c|c|}
\hline Kişisel Özellikler & & & $\mathrm{N}$ \\
\hline \multirow{14}{*}{ Yöneticiler } & \multirow{4}{*}{$\begin{array}{l}\text { Mezun Olunan } \\
\text { Fakülte }\end{array}$} & Eğitim Fak. & 6 \\
\hline & & Teknik Eğitim Fak. & 2 \\
\hline & & İlahiyat Fak. & 1 \\
\hline & & Fen-Edebiyat Fak. & 1 \\
\hline & $\begin{array}{l}\text { Eğitim } \\
\text { Durumu }\end{array}$ & Lisans & 10 \\
\hline & \multirow{4}{*}{$\begin{array}{l}\text { Görev Yaptığ } 1 \\
\text { Okul Türü }\end{array}$} & Anadolu Lisesi & 7 \\
\hline & & Fen Lisesi & 1 \\
\hline & & Mesleki ve Teknik Anadolu Lisesi & 1 \\
\hline & & Sosyal Bilimler Lisesi & 1 \\
\hline & \multirow{5}{*}{$\begin{array}{l}\text { Mesleki } \\
\text { Kidem }\end{array}$} & $1-5$ y1l & 3 \\
\hline & & $6-10$ y1l & 2 \\
\hline & & $11-15$ y1l & 1 \\
\hline & & $16-20$ y1l & 2 \\
\hline & & 21 yıl ve üstü & 2 \\
\hline
\end{tabular}




\begin{tabular}{|c|c|c|c|}
\hline \multirow{21}{*}{ Öğretmenler } & \multirow{7}{*}{ Branş } & Türk Dili ve Edebiyatı & 4 \\
\hline & & Matematik & 4 \\
\hline & & Fizik & 3 \\
\hline & & Tarih & 3 \\
\hline & & İngilizce & 2 \\
\hline & & Coğrafya & 2 \\
\hline & & Biyoloji & 2 \\
\hline & \multirow{2}{*}{$\begin{array}{l}\text { Mezun Olunan } \\
\text { Fakülte }\end{array}$} & Fen-Edebiyat Fak. & 15 \\
\hline & & Eğitim Fak. & 5 \\
\hline & \multirow{3}{*}{$\begin{array}{l}\text { Eğitim } \\
\text { Durumu }\end{array}$} & Lisans & 12 \\
\hline & & Tezsiz Yüksek Lisans & 5 \\
\hline & & Tezli Yüksek Lisans & 3 \\
\hline & \multirow{4}{*}{$\begin{array}{l}\text { Görev Yaptığ } 1 \\
\text { Okul Türü }\end{array}$} & Anadolu Lisesi & 11 \\
\hline & & Mesleki ve Teknik Anadolu Lisesi & 6 \\
\hline & & Fen Lisesi & 2 \\
\hline & & Anadolu İmam Hatip Lisesi & 1 \\
\hline & \multirow{5}{*}{$\begin{array}{l}\text { Mesleki } \\
\text { Kidem }\end{array}$} & $1-5$ y1l & 4 \\
\hline & & $6-10$ y1l & 2 \\
\hline & & $11-15$ y1l & 3 \\
\hline & & $16-20 \mathrm{y} 11$ & 6 \\
\hline & & 21 y1l ve üstü & 5 \\
\hline
\end{tabular}

Tablo 1 incelendiğinde çalışmaya katılan yöneticilerin ve öğretmenlerin, yoğun olarak eğitim (11) ve fen-edebiyat (16) fakültesi mezunu olduğu görülmektedir. Öğrenim durumu olarak bakıldığında okul yöneticilerinin tamamının lisans mezunu, öğretmenlerin ise 12'sinin lisans, 3'ünün tezli yüksek lisans ve 5'inin tezsiz yüksek lisan mezunu olduğu görülmektedir. Okul türü bakımından incelendiğinde katılımc1ların, 18'inin Anadolu Lisesi'nde, 7'sinin Mesleki ve Teknik Anadolu Lisesi'nde, 3'ünün Fen Lisesi'nde ve 3'ünün Sosyal Bilimler Lisesi'nde görev yapan kişilerden oluştuğu görülmektedir. Kıdem yılı bazında incelendiğinde araştırmaya katılanların, 7'sinin 21 yıl ve üzerinde, 8'inin 16-20 yıl arasında, 4'ünün 11-15 yıl arasında, 4'ünün 6-10 y1l arasında ve 7'sinin 1-5 yıl arasında görev sürelerinin olduğu görülmektedir. Branş bazında incelendiğinde araştırmaya katılan öğretmenlerin, 4'ünün Türk Dili ve Edebiyat1, 4'ünün Matematik, 3'ünün Fizik, 3'ünün Tarih, 2'sinin İngilizce, 2'sinin Coğrafya ve 2'sinin Biyoloji branşında görev yaptığı görülmektedir. Ayrıca katılımcıların EBA ilgili deneyimlerinin olmasına dikkat edilmiştir.

\subsubsection{Araştırmacıların Özellikleri}

Bu çalışmada yer alan 2 araştırmacıda nitel araştırma konusunda deneyim sahibi ve daha önce dijital öğrenme ortamları üzerinde çalışmalar gerçekleştirmiştir.

\subsection{Veri Toplama Aracı}

Araştırmanın nitel verileri, araştırmacılar tarafından geliştirilen yarı yapılandırılmış görüşme formu aracılığı ile toplanmıştır. Yapılan görüşme esnasında; esnek bir şekilde değişen koşullara uyum sağlayabilmesi, anında geribildirim sağlanabilmesi, cevaplarda öznelliğin korunabilmesi, yanlış anlamaların azaltılabilmesi gibi özelliklerinden (Yılmaz, 2011, s. 5) dolay1 "Yarı-yapılandırılmış görüşme tekniği" tercih edilmiştir. Geliştirilen görüşme formu, alan uzmanları tarafından incelenmiştir. İnceleme neticesinde, bazı açık uçlu soruların daha anlaşır, açık ve net ifadeler olması gerektiği söylenmiştir. Yapılan dönütler doğrultusunda gerekli düzenlemeler yapılarak formun son hali elde edilmiştir. Görüşme formu, toplam 16 sorudan oluşmaktadır. Görüşme formunda, katılımcıların demografik özelliklerini belirlemeye yönelik 5 soru bulunmaktadır (mezun olduğu fakülte, eğitim durumu, çalıştığ1 okul türü, meslekteki yılı ve branş). Görüşme formunda, katılımcıların teknoloji kullanım bilgileri, EBA 
eğitim düzeyleri, EBA Akademik Destek Platformu arayüzü ve içerik kullanımları ile ilgili görüşlerini belirlemeye yönelik 11 soru bulunmaktadır.

\subsection{Verilerin Toplanması}

Verilerin toplanmasında, uzman görüşlerinden sonra son hali verilen yarı yapılandırılmış görüşme formu kullanılmıştır. Görüşme formu kullanılarak, ortaöğretim okullarında görev yapan 10 okul yöneticisi ve 20 öğretmen ile görüşülmüştür. Pandemi sürecinden dolayı ve katılımcıların da isteği üzerine katılımcı görüşleri, yazılı olarak ya da online form kullanılarak toplanmıştır. Uygulama esnasında anlaşılmayan noktaların araştırmacıya sorulması konusunda katılımcılara gerekli bilgilendirme yapılmıştır. Katılımcıların soruları yönlendirme olmaksızın cevaplamaları sağlanmıştır. Araştırmacılar, 30 katılımcı ile görüşme yaptıktan sonra toplanan verileri incelemiş ve inceleme sonucu verilerin tekrar etmeye (verilerin doyuma ulaşması) başlaması üzerine veri toplama sürecini sonlandırma kararı vermişlerdir.

\subsection{Verilerin Analizi}

İçerik analizi, yazılı hale getirilen verilerin kavramsallaştırılarak ortaya çıkan kavramları mantıklı bir şekilde sıralayıp ortak bir tema altında saptanması tekniğidir (Strauss ve Corbin, 1990, s. 61). Olgu bilim çalışmalarında veri analizi, yaşantıları ve anlamları ortaya çıkarmayı amaçlamaktadır. $\mathrm{Bu}$ amaç doğrultusunda yapılan içerik analizinde, olguyu tanımlayabilecek ve verinin kavramsallaştırılmasını sağlayabilecek temaların elde edilme çabası vardır. Sonuçlar sunulurken katılımcıların ifadelerinden doğrudan alıntılara yer verilir (Yıldırım ve Şimşek, 2011, s. 260). Bu araştırmada, okul yöneticilerinin ve öğretmenlerin görüşleri alındıktan sonra sorulara verilen cevaplar bir araya toplanmış ve araştırmaya yansıtılmıştır. Çalışmada katılımcıların vermiş oldukları cevaplar; okul yöneticileri için Y1, Y2, Y3... öğretmenler için Ö1, Ö2, Ö3... şeklinde kodlanmıştır. Ayrıca, metnin ana düşüncesini desteklemek için gerekli görülen yerlerde görüşme metinlerinden doğrudan alıntılama yoluna gidilmiştir. Verilerin çözümlemesi yapılırken, okul yöneticilerinin ve öğretmenlerin görüşlerinde değişiklik yapılmadan görüşler araştırmaya yansıtılmıştır.

$\mathrm{Bu}$ çalışmada içerik analiz bağlamında eksensel ve IN vivo (Saldana, 2015, s. 77) kodlamalar yapılmıştır. Eksensel kodlamada elde edilen veriler, bir eksen üzerine konumlandırılır. Yerleştirme esnasında ortaya çıkan kategorilerin ve kodların arasındaki ilişkiler incelenerek ve bunlar arasında bağlantı kurularak verilerin yeniden bir araya getirilmesi sağlanır (Strauss ve Corbin, 1998, s. 156; Özalpman, 2010, s. 126). In vivo kodlamada ise araştırmac1, bazı durumlarda verileri birebir alarak kategoriler ya da kodlar oluşturmaktadır (Özsoy ve Çetinkaya, 2014, s. 159). Eksensel kodlama sürecinde, 1., 4., 5., 6., 7., 8., ve 9. sorular eksen olarak kabul edilmiştir. Bu sorular üzerinden yöneticilerin ve öğretmenlerin görüşleri ile kodlama gerçekleştirilmiş ve frekans olarak bulgulara yansıtılmıştır. 2., 3. ve 10. sorular bağlamında ise IN vivo kodlama yapılmıştır. Bu bağlamda görüşmelerden elde edilen veriler olduğu gibi kod kabul edilmiştir. Bu kodlama sürecinde elde edilen kodların frekansları bulgulara yansitılmıştır.

\subsection{Tutarlılık, Teyit Edilebilirlik, Aktarılabilirlik, İnandırıcılık}

Çalışmada inandırıcılığı (iç geçerliliği) sağlamak için katılımcılarla uzun ve derin bir etkileşim kurulmuştur. Araştırmacılar, katılımcıların verdiği cevapları doğru anlayıncaya kadar iletişime devam etmişlerdir. Gerektiğinde cevaplar yeniden alınmıştır. Yapılan kodlamaya ve araştırmacıların yorumu için kalıtımcılardan dönüt ve teyit alınmıştır. Çalışmanın aktarılabilirliğini (dış geçerlilik) sağlamak için veri toplama sürecine ve yapılan kodlamalara ilişkin (eksensel ve In vivo kodlama) ayrıntılı betimlemeler yapılmıştır. Bu betimlemeler, bulgular bölümünde tablolara yansıtılmıştır. Ayrıca amaçlı örnekleme türlerinden maksimum çeşitlilik örneklemesi kullanılmıştır. Çalışmada tutarlıı̆̆ı (iç güvenirlik) sağlamak amacıyla, kodlama alanlarının, seçili sorunsalın ve çalışma kapsamının dışına çıkılmaması adına diğer bir 
eğitim yönetimi uzmanının görüşü alınmıştır. Böylece çalışmanın bir bütünlük göstermesi üçüncü bir uzman tarafından takip edilmiştir. Çalışmanın teyit edilebilirliğini (dış güvenirlik) sağlamak için kodlama sürecinde (analiz sürecinde) nitel araştırma süreçlerinde deneyim sahibi bir uzmanının görüşleri de alınmıştır. Daha sonra elde edilen kodlar üzerinden araştırmacılar yorumlarını çalışmaya yansıtmışlardır.

\subsection{Etik}

Çalışma kapsamında Erzincan Binali Yıldırım Üniversitesi Etik Kurul Başkanlığına başvuru yapılmıştır. Yapılan değerlendirme sonucu alınan 29/05/2020 tarih ve 05/18 sayılı karar neticesinde başvurumuz etik açıdan uygun bulunmuşstur.

\section{Bulgular ve Yorum}

Araştırmanın bu kısmında EBA Akademik Destek Platformu'na ilişkin ortaöğretimde görev yapan okul yöneticilerinin ve öğretmenlerin genel görüşleri tablolaştırılmış ve katılımcıların görüşlerinden alıntılar yapılarak yorumlanmıştır.

\section{Alt Probleme Ait Bulgular}

Okul Yöneticilerinin ve Öğretmenlerin, Teknolojik Araçları (Bilgisayar, Etkileşimli Tahta Gibi) Kullanma Yeterliliği Hakkındaki Düşünceleri

Okul yöneticilerinin ve öğretmenlerin, teknolojik araçları (bilgisayar, etkileşimli tahta gibi) kullanma yeterliliği hakkındaki düşüncelerine ilişkin eksensel kodlamaya ait veriler Tablo 2 'de verilmiştir.

Tablo 2. Okul yöneticilerinin ve öğretmenlerin teknolojik araçları kullanma yeterliliğine ilişkin eksensel kodlama

\begin{tabular}{lll}
\hline & Kod & f \\
\hline \multirow{3}{*}{ Yöneticiler } & Orta & 4 \\
\cline { 2 - 3 } & İyi & 4 \\
\cline { 2 - 3 } & Çok İyi & 2 \\
\hline \multirow{3}{*}{ Öğretmenler } & Orta & 9 \\
\cline { 2 - 3 } & İyi & 5 \\
\cline { 2 - 3 } & Çok İyi & \\
\hline
\end{tabular}

Tablo 2'de görüldüğü gibi teknolojik araçları kullanma yeterliliği ile ilgili soruya okul yöneticilerinin, 4'ü orta düzeyde, 4'ü iyi düzeyde ve 2'si çok iyi düzeyde teknolojik araçları kullandıklarını ifade etmiş̧lerdir. Araştırmaya katılan öğretmenlerin ise 9'u orta düzeyde, 6'sı iyi düzeyde ve 5'i çok iyi düzeyde teknolojik araçları kullandıklarını ifade etmişlerdir. Tablo 2'deki veriler doğrultusunda araştırmaya katılan katılımcıların, teknolojik araçları eğitim-öğretim ortamlarında kullanabilecekleri öngörüsü ortaya çıkmaktadır.

\section{Alt Probleme Ait Bulgular}

\section{Okul Yöneticilerinin ve Öğretmenlerin EBA Akademik Destek Platformu'na Yönelik Eğitim Durumları ve Alınan Eğitim Hakkındaki Görüşleri}

Okul yöneticilerinin ve öğretmenlerin, EBA Akademik Destek Platformu'na yönelik bir eğitim alıp almadıkları ile ilgili durumları ve aldıkları eğitimle ilgili okul yöneticisi ve öğretmen görüşlerine ilişkin In vivo kodlamaya ait veriler Tablo 3 'te verilmiştir.

Tablo 3. Platform ile ilgili eğitim durumları ve eğitime ait görüşlerine ilişkin In vivo kodlama

\begin{tabular}{llll}
\hline & In Vivo Kod & Kod & $\mathrm{f}$ \\
\hline \multirow{3}{*}{ Yöneticiler } & \multirow{3}{*}{ Evet, Eğitim Aldım } & Orta Düzeyde & 3 \\
\cline { 3 - 4 } & & İyi Düzeyde & 1 \\
\cline { 3 - 4 } & & Çok İyi Düzeyde & 3 \\
\hline
\end{tabular}




\begin{tabular}{|c|c|c|c|}
\hline & Hayır, Eğitim Almadım & \multirow[t]{2}{*}{-} & \multirow[t]{2}{*}{3} \\
\hline & Öğretmenleri $\quad$ Akademik & & \\
\hline & $\begin{array}{l}\text { Destek Platformu ile ilgili } \\
\text { herhangi bir eğitime } \\
\text { yönlendirdiniz mi? }\end{array}$ & Hayır Yönlendirmedim & 10 \\
\hline \multirow{4}{*}{ Öğretmenler } & \multirow{3}{*}{ Evet, Eğitim Aldım } & Orta Düzeyde & 4 \\
\hline & & İyi Düzeyde & 5 \\
\hline & & Çok İyi Düzeyde & 2 \\
\hline & Hayır, Eğitim Almadım & - & 9 \\
\hline
\end{tabular}

Tablo 3’te görüldüğü gibi araştırmaya katılan okul yöneticilerinin, 3’ünün hiçbir eğitim almadığı, 3'ünün orta düzeyde eğitim aldığı, 1'inin iyi düzeyde eğitim aldığı ve 3'ünün çok iyi düzeyde eğitim aldığı görülmektedir. Araştırmaya katılan öğretmenlerin, 9'unun hiçbir eğitim almadığı, 4'ünün orta düzeyde eğitim aldığı, 5'inin iyi düzeyde eğitim aldığı ve 2'sinin çok iyi düzeyde eğitim aldığı görülmektedir. Çalışmaya katılan okul yöneticilerinden ve öğretmenlerden bazılarının görüşleri aşağıdaki gibidir:

"Evet, eğitim aldım. Bilişsim Teknolojileri Öğretmeni tarafindan okul içinde bir eğitim verildi. Verimli bir sunumdu. Öğretmenleri herhangi bir hizmet içi eğitime yönlendirmedim." Y1.

"Evet, eğitim aldım. Okul Formatör öğretmeni tarafindan bir eğitim verildi. Eğitim gayet yeterli ve verimliydi. Öğretmenleri kursa yönlendirmedim.” Y5.

“Aldım. Orta düzeydeydi.” Y2.

“Okulumuz Bilişim Teknolojileri Öğretmeni tarafindan site içeriği ve kullanımı ile ilgili bilgilendirme toplantısı şeklinde bir eğitim verildi." Ö2.

"Eğitim aldım. Seminer olarak klsa bir eğitimdi." Ö6.

“Evet. Yüzeysel.” Ö20.

Okul yöneticilerinin görüşleri dikkate alındığında, öğretmenleri EBA Akademik Destek Platformu ile ilgili herhangi bir hizmet içi eğitime ya da kursa yönlendirmedikleri görülmüştür. EBA Akademik Destek Platformu ile ilgili öğretmenlere verilen eğitimlerin, okul bünyesinde bilişim teknolojileri öğretmeni tarafından verildiği söylenebilir. Katılımcıların verdiği cevaplar incelendiğinde verilen eğitimin herhangi bir planlama olmadan kısa bir seminer gibi verildiği görülmektedir. Oysaki bu tür eğitimler bir plan kapsamında yapılmalı ve kişinin inisiyatifine bırakılmamalıdır. Çünkü kullanılan teknoloji ne kadar yeni olursa olsun iyi eğitilmiş bir kullanıcı olmazsa o teknoloji amacına ulaşamayacaktır.

\section{Alt Probleme Ait Bulgular}

\section{Okul Yöneticilerinin, Öğretmenlerin EBA Akademik Destek Platformu'na Yönelik Algıları Konusundaki Görüşleri}

Okul yöneticilerinin gözünden EBA Akademik Destek Platformu ile ilgili öğretmen algılarına ilişkin In Vivo kodlamaya ait veriler Tablo 4'te verilmiştir.

Tablo 4. Okul yöneticilerinin gözünden öğretmenlerin EBA Akademik Destek Platformu ile ilgili algılarına ilişkin In vivo kodlama

\begin{tabular}{ll}
\hline In Vivo Kodları & f \\
\hline Akademik Destek Platformu, başarılı ve kullanışlı bir platform & 10 \\
\hline Akademik Destek Platformu'nda YKS'ye yönelik içerik (kazanım) eksikliği bulunmakta & 5 \\
\hline Akademik Destek Platformu'ndaki test, deneme gibi destekleyici kaynak yetersizliği & 5 \\
\hline Akademik Destek Platformu teknoloji bağımlılığına neden olabilir & 2 \\
\hline
\end{tabular}


Tablo 4'te de görüldüğü üzere okul yöneticilerinin gözünden öğretmen görüşleri incelendiğinde, okul yöneticilerinin tamamı öğretmenlerin Akademik Destek Platformu'nu başarılı ve kullanışlı bir platform olarak gördüğünü dile getirmişlerdir. Okul yöneticilerinin 5'i Akademik Destek Platformu'nda YKS'ye yönelik içerik (kazanım) eksikliğinin olduğunu, 5'i ise test, deneme gibi destekleyici kaynakların yeterli olmadığını öğretmenlerin dile getirdiğini ifade etmektedirler. Ayrıca, okul yöneticilerinin 2'si öğretmenlerin EBA Akademik Destek Platformu'nun teknoloji bağımlılığına neden olabileceğini dile getirdiklerini ifade etmektedirler. Çalışmaya katılan okul yöneticilerinden bazılarının görüşleri aşağıdaki gibidir:

"İçerik eksikliğinin olduğunu ve geliştirilmesi gerektiğini söylediler. Özellikle İngilizce Öğretmenleri, içeriğinin olmamasından dertliydi." Y1.

"Öğretmenlerin bazıları ögrenci potansiyeli ve hazır bulunuşluklarından dolayı çok kullanma taraftarı değiller." Y4.

“Öğretmenlerin geneli Akademik Destek Platformu'nu başarll buluyorlar. Hem kullanışl hem de verimli içeriklere sahip olduğunu dile getirdiler. Belirli sayıda öğretmenimiz ise bu sistemin gençlerimizi daha fazla teknoloji bağımlılı̆̆ına yönelteceğini savunmaktadır." Y5.

"Genel görüsler iyi yönde olmakla birlikte eleştiren ögretmenler de bulunmaktadır. Özellikle konu anlatımı ve soru çeşitlerinin bazı branşlarda yeterli olmadı̆̆ söylenmektedir." Y8.

Yönetici görüşleri dikkate alındığında, öğretmenlerin platform ile ilgili genel görüşlerinin olumlu olduğu söylenebilir. Ayrıca, YKS'ye yönelik olan platformun içerik olarak eksik olduğu ve geliştirilmesi gerektiği düşüncesinin yaygın olduğu görülmektedir. Sınava yönelik geliştirilen bu platformun, içerik olarak eksiklerinin biran önce giderilmesi platformun daha aktif ve verimli kullanılması için önemli görülmektedir.

\section{Alt Probleme Ait Bulgular}

\section{Platformda Yer Alan Yönetici ve Öğretmen Arayüzünün Kullanışlılık Durumu Hakkındaki Yönetici ve Öğretmen Görüşleri}

EBA Akademik Destek Platformu yönetici ve öğretmen arayüzü hakkında okul yöneticilerinin ve öğretmenlerin görüşlerine ilişkin eksensel kodlamaya ait veriler Tablo 5'te verilmiştir.

Tablo 5. Okul yöneticilerinin ve öğretmenlerin, EBA Akademik Destek Platformu okul yöneticisi ve öğretmen arayüzü hakkındaki görüşlerine ilişkin eksensel kodlama

\begin{tabular}{|c|c|c|c|}
\hline & Kod & Alt kod & $\mathrm{f}$ \\
\hline \multirow{4}{*}{ Yöneticiler } & Arayüz Görünümü & Sade & 10 \\
\hline & Kullanım Kolaylığı & Kolay & 10 \\
\hline & \multirow{2}{*}{ Menüler ve Özellikler } & Yeterli & 7 \\
\hline & & Geliştirilmeli & 3 \\
\hline \multirow{6}{*}{ Öğretmenler } & \multirow{2}{*}{ Arayüz Görünümü } & Sade & 18 \\
\hline & & Karmaşık & 2 \\
\hline & \multirow{2}{*}{ Kullanım Kolaylığı } & Kolay & 18 \\
\hline & & Zor & 2 \\
\hline & \multirow{2}{*}{ Menüler ve Özellikler } & Yeterli & 14 \\
\hline & & Geliştirilmeli & 6 \\
\hline
\end{tabular}

Tablo 5 'te görüldüğü üzere okul yöneticilerinin tamamı, yönetici arayüz görünümünün sade ve kullanımının kolay olduğunu söylemişlerdir. Okul yöneticilerinin 3'ü mevcut menü ve özelliklerin geliştirilmesi gerektiğini söylerken, 7'si bu mevcut durumun yeterli olduğunu dile getirmişlerdir. Araştırmaya katılan öğretmenlerin 18'i öğretmen arayüz görünümünün sade ve 
kullanımının kolay olduğunu söylerken, 2'si ise karmaşık ve zor olduğunu dile getirmişlerdir. Öğretmenlerin 14'ü mevcut menü ve özelliklerin yeterli olduğu görüşünde iken 6's1 geliştirilmesi gerektiğini dile getirmişlerdir. Çalışmaya katılan okul yöneticilerinden ve öğretmenlerden bazılarının görüşleri aşağıdaki gibidir:

"Arayüz sade ve kullanışl fakat raporlama kısmında eksikler var. Verilen etütlere ya da ödevlere bakıldığında tüm çalışmalar karşıma gelmektedir. Filtre özelliği bir tek öğretmen bazlı bulunmakta ders bazlı da olursa daha kullanışlı olabilir.” Y1.

"Gayet kullanışlı ve basit bir arayüze sahip. Arayüzün rol değiştirme özelliği çok iyi, istediğiniz zaman ögretmen rolüne geçebiliyorsunuz hatta aynı zamanda veli iseniz veli rolüne de geçiş imkanı sağllyor..." Y2.

"Bu platformu yönetici olarak kullanışlı buluyorum. Özellikle yönetici arayüzündeki raporlar bölümü işlerimi bir hayli kolaylaştırmakta..." Y9.

"Kesinlikle kullanışlı. Gönderdiğim tüm testler için soru bazında, sınıf bazında, öğrenci bazında, toplu ve ayrı ayr olmak üzere detayl analiz sonuçları alabiliyorum... Normalde tanımadı̆̆ım öğrencileri bu uygulama sayesinde daha iyi tanıma imkânı buldum." Ö8.

“Tüm branş isteklerine uygun hale getirilmeli daha basit kullanım sunulmalı.” Ö11.

"Öğrencinin takibi daha kolay bir hal aldı. Raporlama kısmı çok iyi. Yapay zekâsı sayesinde ögrencileri süreç içinde hedeften haberdar edip yeni hedefler belirlemesi artı yönlerindendir. İçerik ve soru çeşitliliği daha da fazla olabilir. " Ö16.

Katılımcıların görüşleri incelendiğinde yönetici ve öğretmen arayüzünün sade ve kullanışlı olduğu görüşünün yaygın olduğu görülmektedir. Teknolojinin sürekli gelişmesi ve ihtiyaçların değişmesi ile platformun arayüz ve özellik bakımından geliştirilmesi gerektiği düşünülmektedir.

\section{Alt Probleme Ait Bulgular}

EBA Akademik Destek Platformu'nun Eğitim-Öğretim Sürecinde Aktif Kullanılması Sonucu Okul Yöneticilerinin, Eğitim-Öğretime Yönelik Hedeflerinde ve Stratejilerinde Değişiklik Olup Olmadığına Yönelik Yönetici Görüşleri

EBA Akademik Destek Platformu'nun aktif kullanılması ile eğitim-öğretime yönelik okul hedeflerinde ve stratejilerinde değişiklik olma durumu hakkında okul yönetici görüşlerine ilişkin eksensel kodlamaya ait veriler Tablo 6'da verilmiştir.

Tablo 6. EBA Akademik Destek Platformu'nun aktif kullanılması ile okul yöneticilerinin, eğitim-öğretime yönelik okul hedeflerinde ve stratejilerinde değişiklik olma durumu hakkındaki görüşlerine ilişkin eksensel kodlama

\begin{tabular}{llll}
\hline \multirow{2}{*}{ Yöneticiler } & Kod & Alt Kod & f \\
\cline { 3 - 4 } & \multirow{2}{*}{ Okul hedef ve stratejileri } & Değişiklik olmadı & 8 \\
\cline { 3 - 4 } & & Değişiklik oldu & 2 \\
\hline
\end{tabular}

Tablo 6' da görüldüğü üzere okul yöneticilerinin, 8'i hedef ve stratejilerinde herhangi bir değişikliğe gitmediklerini, 2'si ise hedeflerinde ve stratejilerinde değişikliğe gittiklerini ifade etmişlerdir. Katılımcılara ait bazı görüşler aşağıdaki gibidir:

"Yeni bir arayüz olduğu için bu platform baz alınarak herhangi bir değişiklik yapmadik." $\mathrm{Y} 2$.

"Evet oldu. Öğretmenler teknoloji ve bilişim anlaminda iyi bir rehber olmak zorunda. Sadece alanında çok iyi olması yetmiyor teknolojiyi de iyi kullanmaları gerekiyor. Ciddi hizmet içi eğitim almalarını hedefledik." Y3. 
"Yeni bir arayüz ve geliştirilmesi gereken yönlerinin olmasından dolayı hedeflerimizde bir değişikliğe gidilmedi." Y9.

"Bu arayüz ikinci dönem faaliyete geçtiği için herhangi bir değişiklik olmadı." Y10.

Cevaplar analiz edildiğinde hedeflerde ve stratejilerde herhangi bir değiş̧ikliğe gidilmemesinin sebebi olarak, platformun yeni ve geliştirilmesi gerektiği ve eğitim-öğretimin ikinci döneminde faaliyete girmesi söylenebilir.

\section{Alt Probleme Ait Bulgular}

EBA Akademik Destek Platformu'nun, Öğretmenler Tarafından Eğitim-Öğretim Sürecinde Aktif Kullanılması İle Birlikte Öğretmenlerin, Ders Bazlı Hedeflerinde Değişiklik Olup Olmadığına Yönelik Görüşleri

EBA Akademik Destek Platformu'nun aktif kullanılması ile öğretmenlerin ders bazındaki hedeflerinde değişiklik olma durumu hakkında öğretmen görüşlerine ilişkin eksensel kodlamaya ait veriler Tablo 7'de verilmiştir.

Tablo 7. EBA Akademik Destek Platformu'nun aktif kullanılması ile öğretmenlerin, ders bazındaki hedeflerinde ve stratejilerinde değişiklik olma durumu hakkındaki görüşlerine ilişkin eksensel kodlama

\begin{tabular}{llll}
\hline & Kod & Alt Kod & f \\
\hline \multirow{2}{*}{ Öğretmenler } & \multirow{2}{*}{ Ders bazlı hedefler } & Değişiklik olmadı & 14 \\
\cline { 3 - 4 } & & Değişiklik oldu & 6 \\
\hline
\end{tabular}

Tablo 7'de görüldüğü üzere öğretmenlerin, 14'ü ders bazındaki hedeflerinde ve stratejilerinde herhangi bir değişikliğe gitmediklerini, 6's1 ise hedeflerinde ve stratejilerinde değişikliğe gittiklerini ifade etmişlerdir. Katılımcılara ait bazı görüşler aşağıdaki gibidir:

"12.siniflarla daha çok test ve deneme çözebiliyoruz. Bu yönde test, deneme ve net hedeflerimde değişikliğe gittim." Ö4.

"Hayır, ders bazında hedeflerimde hiçbir değişiklik olmadı. Dersin hedefi uygulamaya göre değişmez." Ö9.

"Okul türümüzden dolayı hedeflerimizde herhangi bir değişiklik olmadı. EBA Akademik Destek'i sadece hedeflerimize hizmet eden bir platform olarak görüyorum.” Ö16.

"Arayüzün yeni olmasl ve tam olarak derslerimde kullanmadı̆̆ımdan dolayı dersime ait hedeflerimde herhangi bir değişiklik olmadı." Ö18.

Cevaplar analiz edildiğinde katılımcıların herhangi bir değişikliğe gitmemesinin sebebi olarak, platformun yeni ve geliştirilmesi gerektiği söylenebilir. Hedeflerinde değişiklik yapacağını dile getiren katılımcılar ise bu hedeflerini faaliyete geçirmek için girişimlerde bulunduklarını söylemişlerdir.

\section{Alt Probleme Ait Bulgular}

EBA Akademik Destek Platformu'ndaki Öğretmenlere Ait Verilerin, Öğretmen Performansını Değerlendirmede Okul Yöneticileri Tarafından Kullanılmasına Yönelik Okul Yöneticilerinin Görüşleri

EBA Akademik Destek Platformu'ndaki öğretmene ait verilerin, öğretmen performansını değerlendirmede okul yöneticileri tarafından kullanılması hakkındaki okul yöneticisi görüşlerine ilişkin eksensel kodlamaya ait veriler Tablo 8'de verilmiştir. 
Tablo 8. EBA Akademik Destek Platformu'ndaki öğretmen verilerinin, öğretmen performansını değerlendirmede okul yöneticileri tarafından kullanılmasına yönelik okul yöneticilerinin görüşlerine ilişkin eksensel kodlama

\begin{tabular}{|c|c|c|c|}
\hline & Kod & Alt kod & $\mathrm{f}$ \\
\hline \multirow{2}{*}{$\begin{array}{l}\text { Yöneticiler } \\
-\end{array}$} & \multirow{2}{*}{$\begin{array}{l}\text { Mevcut eğitim- } \\
\text { döneminde }\end{array}$} & Kullanmiyorum & 8 \\
\hline & & Kullaniyorum & 2 \\
\hline \multirow{2}{*}{$\begin{array}{l}\text { EBA Akademik Destek } \\
\text { Platformundaki öğretmen } \\
\text { verilerini performanslarını } \\
\text { değerlendirirken }\end{array}$} & \multirow[b]{2}{*}{$\begin{array}{l}\text { Sonraki eğitim- } \\
\text { döneminde }\end{array}$} & Kullanmayı düşünüyorum & 7 \\
\hline & & $\begin{array}{l}\text { Kullanmayı } \\
\text { düşünmüyorum }\end{array}$ & 3 \\
\hline
\end{tabular}

Tablo 8'de görüldüğü üzere okul yöneticilerinin, 8'i mevcut eğitim-öğretim döneminde öğretmen performansını değerlendirirken platformdaki öğretmen verilerini kullanmadığını, 2'si ise kullandığını ifade etmişlerdir. Sonraki eğitim-öğretim dönemlerinde ise okul yöneticilerinin, 7'si bu verileri öğretmen performansını değerlendirirken kullanmayı düşündügü̈, 3’ü ise kullanmayı düşünmediğini ifade etmişlerdir. Çalışmaya katılan okul yöneticilerinden bazılarının görüşleri aşağıdaki gibidir:

"Hayır kullanmıyorum. Çünkü sırf çalışmak için öğrencileri ödev ve etüt yoğunluğuna boğabilirler. Yani sadece göstermelik bir çalı̧̧ma olur. Ayrica çok yeni bir platform, tam verimli olarak kullandıklarını düşünmüyorum. Yani çok iyi bir ögretmen bu platforma bu kadar kısa sürede hakim olamayabilir. Fakat belirli bir aşamadan sonra ögretmen performansinı değerlendirmede bir kriter olarak kullanabilirim." Y2.

"Evet kullanıyorum. İyi bir rehber ve danışman olabiliyor mu? Çağın şartlarına uyum să̆llyor mu? Öğrencilerini bunlarla verimli şekilde buluşturup hizmet almalarını săgllyor mu?" $\mathrm{Y} 3$.

“Şu aşamada kullanmayı düşünmüyorum. Çünkü ögretmenlere özel bir raporlama ya da takip arayüzü geliştirilmemiş sadece bir kaç işlemi görebiliyorsunuz. Öğretmen performansını sadece bir iki basamak ile değerlendiremezsiniz. Bu konudaki raporlama özelliği geliştirilmelidir. Fakat bu platformun tam oturması ile ögretmenlerin genel performansının değerlendirilmesinde bir kriter olarak kullanılabilir." Y5.

"Hayır kullanmıyorum. Çünkü bu platform henüz çok yeni olduğu için her ögretmen hâkim değil. Ancak daha sonraki dönemlerde buradaki verileri de bir kriter olarak performans değerlendirmede kullanmayı düşünüyorum." Y8.

Cevaplar incelendiğinde öğretmen performansını değerlendirmede platformda yer alan öğretmen verilerinin kullanılmamasının sebebi olarak, yeni bir platform olması, öğretmenlerin yeterli bir sürede kullanamaması, platforma tam hakim olunamaması ve ögretmen hakkında detaylı veriler vermemesi söylenebilir. Fakat platformun bütün öğretmenler tarafindan aktif kullanılması ile platformda yer alan öğretmen verilerinin, öğretmen performansını değerlendirmede bir kriter olarak kullanılabileceği görülmektedir.

\section{Alt Probleme Ait Bulgular}

\section{Öğretmenlerin, Platformu Kullanmalarından Dolayı İş Yüklerinde Herhangi Bir Değişiklik Olup Olmadığına Yönelik Görüşleri}

Öğretmenlerin, EBA Akademik Destek Platformu'nu kullanmalarından dolayı iş yükündeki değişiklik ile ilgili öğretmen görüşlerine ilişkin eksensel kodlamaya ait veriler Tablo 9'da verilmiştir. 
Tablo 9. EBA Akademik Destek Platformu'nun kullanılması ile öğretmenlerin iş yüklerindeki değişiklik ile ilgili görüşlerine ilişkin eksensel kodlama

\begin{tabular}{lllll}
\hline & Kod & Alt Kod & $\mathrm{f}$ \\
\hline \multirow{3}{*}{ Öğretmenler } & \multirow{2}{*}{$\begin{array}{l}\text { EBA Akademik Destek } \\
\text { kullanılması ile iş yüküm }\end{array}$} & \multirow{2}{*}{ Platformunun } & Arttı & 11 \\
\cline { 3 - 4 } & & Değişmedi & 7 \\
\cline { 3 - 4 } & & Azald1 & 2 \\
\hline
\end{tabular}

Tablo 9'da görüldügü üzere öğretmenlerin, 7'si iş yükünün değişmediği, 11'i iş yükünün arttığ 1 ve 2'si ise iş yükünün azaldığ 1 yönünde görüş belirtmişlerdir. Çalışmaya katılan öğretmenlerden bazılarının görüşleri aşağıdaki gibidir:

"Evet, bir iş yükü getirdi fakat ögretmenlik mesleği, ögrencinin öğrenmesini să̆lama işi olduğu için bu uygulamanın getirdiği ekstra iş yükü bence tolere edilemez bir şey değil.” Ö9.

"Evet. Evde her akşam 1 saat boyunca dersine girdiğim sinffların durumunu incele, ödev ver, ögrenciden önce sorulara bak ve çöz gibi işlerle uğraşlyorum." Ö14.

"Evet, bir anlamda iş yükü arttı denilebilir fakat (özellikle uzaktan eğitim süreci başlamadan önce) istediğim zaman istediğim yerden uygulamaya girme, raporlart alma, bilgisayarıma veya cep telefonuma raporları indirme imkânı, öğrenci takibi ve öğrenme düzeyinin tespiti açısından büyük katkı sağlıyor.” Ö15.

"Hayır, iş yüküm artmadı. Özellikle sinıfta yapılan soru çözümlerinde iş yükümü azalttı̆ğ dahi oluyor." Ö17.

Cevaplar incelendiğinde iş yükünün artmasının sebebi olarak, platforma ekstra süre ayrılması ve oradaki içeriklerin incelenmesi söylenebilir. Oysaki her zaman yaptığı işlemleri (ödev hazırlama ve inceleme gibi) platformda yaptığı için iş yükünde değişiklik olmadığı, hatta sistemde bulunan soru ve test gibi kaynakları kullandığında iş yükünde azalma olabileceği söylenebilmektedir.

\section{Alt Probleme Ait Bulgular}

\section{EBA Akademik Destek Platformu'nda Yer Alan Branşlarla İlgili İçeriklerin, Öğretim Programında Yer Alan Kazanımlarla Uyumluluğu ve Uygulanabilirliği Hakkındaki Öğretmenlerin Görüssleri}

Öğretmenlerin EBA Akademik Destek Platformu'nda yer alan branşı ile ilgili içeriklerin, öğretim programında yer alan kazanımlarla uyumluluğu ve uygulanabilirliği hakkındaki öğretmen görüşlerine ilişkin eksensel kodlamaya ait veriler Tablo 10'da verilmiştir.

Tablo 10. EBA Akademik Destek Platformu'nda yer alan derslere ait içeriklerin, öğretim programındaki kazanımlarla uyumluluğu ve uygulanabilirliği hakkındaki öğretmenlerin görüșlerine ilișkin eksensel kodlama

\begin{tabular}{lllll}
\hline & Kod & Alt Kod & $\mathrm{f}$ \\
\hline \multirow{3}{*}{ Öğretmenler } & \begin{tabular}{l} 
EBA Akademik Destek Platformunda \\
\cline { 3 - 5 }
\end{tabular} & $\begin{array}{l}\text { yer alan içerikler, öğretim } \\
\text { programında yer alan kazanımlar ile }\end{array}$ & Uyumlu fakat uygulananamazilir & 15 \\
\cline { 3 - 5 } & & İcrik mevcut değil & 2 \\
\hline
\end{tabular}

Tablo 10'da görüldüğü üzere öğretmenlerin, 15'i içeriklerin öğretim programında yer alan kazanımlarla uyumlu ve uygulanabilir olduğu, 3'ü uyumlu fakat uygulanamaz olduğu ve 2'si branşı ile ilgili içeriklerin olmadığı yönünde görüş bildirmiştir. Verilen cevaplar incelendiğinde içeriği olmayan branşın ingilizce olduğu görülmektedir. Oysaki üniversite giriş sınavında üçüncü oturum Yabancı Dil Testi olmasına rağmen bu yönde bir içerik olmaması EBA Akademik Destek Platformu'nun geliştirilme amacı ile çelişmektedir. Çalışmaya katılan öğretmenlerden bazılarının görüşleri aşağıdaki gibidir:

“Gayet uyumlu. Zamanla içeriklerin daha da zenginleşeceğini umuyorum.” Ö2. 
Ö6.

"Uyumlu ama içerik olarak az sayıda içerik olmasından dolayı kullanılabilir değil."

"Branşıma ait içerikler, öğretim programında olan kazanımlarla uyumlu ve uygulanabilir.” Ö13.

"Kazanımlar uygun ve kullanılabilir. Fakat branş gereği içerikler yeterli değil, içerik sayısı arttırılmalı ve içerikler çeşitlendirilmelidir." Ö16.

Cevaplar incelendiğinde platformda yer alan içeriklerin, kazanımlar ile uyumlu ve derslerde uygulanabilir olduğu söylenebilir. Kazanımlarla uyumlu fakat uygulanamaz diyen katılımcıların branşlarına bakıldığında, içeriklerin sözel içeriklerden oluştuğu ve yoğun bilgi aktarımı olduğu ya da içeriklerin yetersiz olduğu görülmektedir. İçeriklerin uygulanabilirliğini geliştirmek için gerekli çalışmalar muhakkak yapılmalıdır.

\section{Alt Probleme Ait Bulgular}

\section{Okul Yöneticilerinin, EBA Akademik Destek Platformu'nun Olumlu ya da Olumsuz Yönleri Hakkındaki Düşünceleri}

Okul yöneticilerinin, EBA Akademik Destek Platformu'nun olumlu ya da olumsuz yönleri hakkındaki görüşlerine ilişkin In vivo kodlamaya ait veriler Tablo 11'de verilmiştir.

Tablo 11. EBA Akademik Destek Platformu'nun olumlu ya da olumsuz yönleri hakkındaki okul yönetici görüşlerine ilişkin In vivo kodlar

\begin{tabular}{|c|c|c|c|}
\hline & & In vivo Kod & $\mathrm{f}$ \\
\hline \multirow{7}{*}{ Yöneticiler } & \multirow{5}{*}{ Olumlu Yönleri } & $\begin{array}{l}\text { Raporlama hizmeti ile öğretmenlerin ve } \\
\text { yöneticilerin, süreci ve ögrenciyi daha iyi } \\
\text { takip etmesini sağliyor }\end{array}$ & 6 \\
\hline & & $\begin{array}{l}\text { Yapılan işlemler ile ilgili hızlı ve kaliteli } \\
\text { dönütler veriyor }\end{array}$ & 6 \\
\hline & & $\begin{array}{l}\text { Gelişmiş ve kaliteli rehberlik hizmeti } \\
\text { sunuyor }\end{array}$ & 5 \\
\hline & & $\begin{array}{l}\text { Eğitimin ve öğretimin istenilen yerde ve } \\
\text { zamanda yapılmasını sağllyor }\end{array}$ & 3 \\
\hline & & $\begin{array}{l}\text { Öğretmenlere eğitim-öğretim sürecinde } \\
\text { destek sağliyor }\end{array}$ & 2 \\
\hline & \multirow[b]{2}{*}{ Olumsuz Yönleri } & $\begin{array}{l}\text { Sistemsel sıkıntılardan dolayı bazı zamanlar } \\
\text { kullanılamıyor }\end{array}$ & 2 \\
\hline & & $\begin{array}{l}\text { Makineleşmiş, duygusuz, hedeflerinde } \\
\text { kopuk ve bağımlı dijital bir nesil } \\
\text { yetișmesine sebep olabilir }\end{array}$ & 1 \\
\hline
\end{tabular}

Tablo 11'de görüldüğü gibi “EBA Akademik Destek Platformu'nun olumlu ya da olumsuz yönleri ile ilgili görüşleriniz nelerdir?" sorusuna verilen cevaplar analiz edilmiştir. Analiz sonucunda EBA Akademik Destek Platformu'nun olumsuz yönleri hakkında yöneticilerin, 2'si sistemsel sıkıntılardan dolayı bazı zamanlar kullanılamadığını, 1'i ise makineleşmiş duygusuz, hedeflerinde kopuk ve bağımlı dijital bir nesil yetişmesine sebep olabileceğini ifade etmişlerdir. Verilen cevaplar doğrultusunda Akademik Destek Platformu'nun olumlu yönleri hakkında yöneticilerin, 6'sı raporlama hizmeti ile yöneticilerin ve öğretmenlerin eğitim sürecini ve öğrenciyi daha iyi takip edilebilmesini sağladığını, 6'sı yapılan işlemler ile ilgili hızlı ve kaliteli dönütler verdiğini, 5'i gelişmiş ve kaliteli rehberlik hizmeti sunduğunu, 3'ü eğitim-öğretimin istenilen yerde ve zamanda yapılabilmesini sağladığını ve 2'si ise öğretmenlere eğitim-öğretim sürecinde destek sağladığını ifade etmişlerdir. Çalışmaya katılan okul yöneticilerinden bazılarının görüşleri aşağıdaki gibidir: 
"Olumlu yönleri, ögrencilere sanal ve kuvvetli bir rehberlik yapıyor. Sürekli hedefleri ile ilgili ögrencilere dönüt veren bir yapıya sahip. Öte yandan ögretmenlerimizin de elini kuvvetlendiriyor. Özellikle bu tatil günlerinde uzaktan eğitim imkânı sağlıyor." Y1.

“...Platformun kullanılmasiyla, ögretmenle göz göze gelme, duygu alış verişi, kültür ve değerlerin aktarılması imkânının ortadan kalkması, makineleşmiş, ruhsuz ve duygusuz dijital bir nesil yetişmesine sebep olabileceği kaygısı var.” Y3.

"Olumsuz herhangi bir yönü bulunmuyor. Olumlu yönleri ise ögrencilere sanal ve kuvvetli bir rehberlik yapıyor olmasıdır. Sürekli hedefleri ile ilgili ögrencilere dönüt veren bir yapıya sahip. Bu özellik sayesinde ögrencinin hedefinden kopmast zorlaşıyor. Özellikle çă̆ımızda, teknoloji ile iç içe olan ögrencilerimizi düşündüğümüz zaman çok güzel bir platform..." Y4.

“... Öğrenci hedeflerini sürekli güncellemektedir, bu sistem sayesinde öğrenci bazlı takip daha kolay olmaktadır. Sinıf şube bazlı karşılaştırmalar sayesinde okulun genel akademik başarısı ile ilgili genel bilgiler elde edilebilmektedir. Etütler sayesinde eğitim dört duvar arasından slyrılmıştır." Y10.

Yöneticilerin görüşleri dikkate alındığında EBA Akademik Destek Platformu'nun, uzaktan eğitim yapılan bu süreçte yöneticilerin, öğretmenlerin ve öğrencilerin eğitim süreçlerini kesintisiz gerçekleştirmesini sağlayan bir platform olduğu söylenebilir. EBA Akademik Destek Platformu kullandığı yapay zekâ sayesinde öğrencilere, hedefleri ve seviyeleri konusunda sürekli geri dönütler vererek rehberlik etmekte ve öğrencilerin kendi kendilerini denetlemelerine imkân sağlamaktadır.

\section{Alt Probleme Ait Bulgular}

\section{Öğretmenlerin, EBA Akademik Destek Platformu'nun Olumlu ya da Olumsuz Yönleri Hakkındaki Düşünceleri}

Öğretmenlerin, EBA Akademik Destek Platformu'nun olumlu ya da olumsuz yönleri hakkındaki görüşlerine ilişkin In vivo kodlamaya ait veriler Tablo 12'de verilmiştir.

Tablo 12. EBA Akademik Destek Platformunun olumlu ya da olumsuz yönleri hakkındaki öğretmen görüșlerine ilișkin In vivo kodlar

\begin{tabular}{|c|c|c|c|}
\hline & & In vivo Kod & $\mathrm{f}$ \\
\hline \multirow{8}{*}{ Öğretmenler } & \multirow{6}{*}{ Olumlu Yönleri } & $\begin{array}{l}\text { Öğretmenlere eğitim-öğretim sürecinde } \\
\text { destek sağlıyor }\end{array}$ & 15 \\
\hline & & $\begin{array}{l}\text { Yapılan işlemler ile ilgili hızlı ve } \\
\text { kaliteli dönütler veriyor }\end{array}$ & 13 \\
\hline & & $\begin{array}{l}\text { Gelişmiş ve kaliteli rehberlik hizmeti } \\
\text { sunuyor }\end{array}$ & 13 \\
\hline & & $\begin{array}{l}\text { Kaliteli ve kalıcı öğrenme sağlayan bir } \\
\text { uzaktan eğitim platformu }\end{array}$ & 13 \\
\hline & & $\begin{array}{l}\text { Raporlama hizmeti ile öğretmen ve } \\
\text { yöneticilerin süreci ve öğrenciyi daha } \\
\text { iyi takip edilmesini sağlıyor }\end{array}$ & 12 \\
\hline & & $\begin{array}{l}\text { Eğitim-öğretimin istenilen yerde ve } \\
\text { zamanda yapılmasını sağlıyor }\end{array}$ & 8 \\
\hline & \multirow[b]{2}{*}{ Olumsuz Yönleri } & $\begin{array}{l}\text { Branşlara ait içerikler yetersiz ve } \\
\text { geliştirilmeli }\end{array}$ & 6 \\
\hline & & $\begin{array}{l}\text { Makineleşmiş, duygusuz, hedeflerinde } \\
\text { kopuk ve bağıml dijital bir nesil } \\
\text { yetismesine sebep olabilir }\end{array}$ & 5 \\
\hline
\end{tabular}




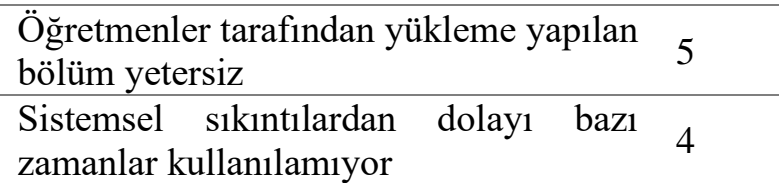

Tablo 12'de görüldüğ̈̈ gibi, “EBA Akademik Destek Platformu'nun olumlu ya da olumsuz yönleri ile ilgili görüşleriniz nelerdir?” sorusuna verilen cevaplar analiz edilmiştir. Analiz sonucunda, EBA Akademik Destek Platformu'nun olumsuz yönleri hakkında öğretmenlerin, 6'sı branşlara ait içeriklerin yetersiz olduğu ve geliştirilmesi gerektiğini, 5'i makineleşmiş duygusuz, hedeflerinden kopuk ve bağımlı dijital bir nesil yetişmesine sebep olabileceğini, 5'i öğretmenler tarafından yükleme yapılan bölümün yetersiz olduğunu ve 4'ü ise sistemsel sıkıntılardan dolayı bazı zamanlar kullanılamadığını ifade etmiştir. Öğretmenlerin, 15'i öğretmenlere eğitim-öğretim sürecinde destek sağladığını, 13'ü yapılan ișlemler ile ilgili hızlı ve kaliteli dönütler verdiğini, 13'ü gelişmiş ve kaliteli rehberlik hizmeti sunduğunu, 13'ü kaliteli ve kalıcı öğrenme sağlayan bir uzaktan eğitim platformu olduğunu, 12'si raporlama hizmeti ile yönetici ve öğretmenlerin eğitim sürecini ve öğrenciyi daha iyi takip edilebilmesini sağladığını ve 8'inin ise eğitim-öğretimin istenilen yerde ve zamanda yapılabilmesini sağladığını ifade etmiştir. Çalışmaya katılan öğretmenlerden bazılarının görüşleri aşağıdaki gibidir:

"Cep telefonlarından da, akademik destek sayfasının kullanilabilir olmasi gerekir. Devam zorunluluğu olmadı̆̆ için ögrenciler platformu kullanmak istemiyorlar. Her ögrencinin evinde bilgisayart ve internet bağlantıst yok..." Ö1.

"Kısa zamanda birden çok öğrenciye aynı anda içerik, ödev, test gönderip bunları kontrol etme şansımız olduğu için oldukça önemli görüyorum.” Ö6.

"Soru kalitesi yükseltilmeli. Platforma girişte hiçbir sıkıntı yaşanmasın diye gerekli çalışmalar yapılmalıdır." Ö10.

"Yapay zekâya sahip olması ve sürekli kendini yenileyebiliyor olması çok olumlu. Öğrenci değerlendirme ve takip sistemi bence çok iyi. Herhangi bir olumsuz yönü bulunmamaktadır." Ö15.

"Öğrenci bazlı takip daha kolay ve ulaşılabilir. Her branştan öğretmen, istediğ ögrenciyi yakın olarak takip edebilir. Öğrencilerin çalışmalarına göre analiz edip dönütler vermesi ve yönlendirmesi harika bir durum. Kısacası sanal ortamdaki ideal bir rehber. Olumsuz yönü ise aşırı kullanılması durumunda teknoloji bağımlllı̆̆ına neden olabilir. Hatta öğrencide farklı sağglı sorunlarının ortaya çıkmasına neden olabilir." Ö17.

Öğretmenlerin görüşleri dikkate alındığında EBA Akademik Destek Platformu'nun, uzaktan eğitim yapılan bu süreçte öğretmenlerin ve öğrencilerin eğitim süreçlerini kesintisiz gerçekleştirmesini sağlayan bir platform olduğu söylenebilir. Eğitim-öğretim süresince öğrenci takibini kolaylaştıran platformun, öğrencilerin kaliteli ve kalıcı öğrenmeler gerçekleştirmesini sağladığı görülmektedir. EBA Akademik Destek Platformu'nda kullanılan yapay zekâ uygulaması ile öğrencilere gelişmiş ve kaliteli rehberlik hizmeti sunulduğu görülmektedir.

EBA Akademik Destek Platformu'nun kesintisiz ve kaliteli bir hizmet verebilmesi için gerekli teknolojik alt yapının ve ders içeriklerinin geliştirilmesi gerektiği söylenebilir. Ayrıca, çok sık kullanılan teknolojik araçlardan dolayı oluşabilecek teknoloji bağımlılığının önüne geçebilmek için öğrencilerimize bu konu ile ilgili bilgilendirici seminerler düzenlenmesi gerektiği söylenebilir.

\section{Tartışma, Sonuç ve Öneriler}

Araştırma sonuçlarına göre hem okul yöneticilerinin hem de öğretmenlerin teknoloji kullanımı konusunda kendilerini yeterli gördükleri ifade edilebilir. Ancak yöneticilerin ve öğretmenlerin, teknolojik gelişmelerin günümüzde çok hızlı bir şekilde gerçekleşmesi 
dolayısıyla kendilerini bu konuda sürekli olarak yenilemeleri hususunda hem fikir oldukları söylenebilir. Eğitimde teknoloji kullanımının son derece önemli bir konu olduğu düşünüldüğünde okul yöneticilerinin, öğretmenlerin, öğrencilerin ve hatta velilerin bu konudaki yeterliliklerinin çağdaş eğitim açısından kritik öneme sahip olduğunu söyleyebiliriz.

Araştırma sonucunda, okul yöneticileri ve ögretmenlerden bir kısmının hiçbir eğitim almadığı ve bir kısmının da orta düzeyde eğitim aldıkları görülmektedir. Alabay ve Taşdelen (2017) tarafından yapılan araştırmada da bu sonucun desteklendiği görülmektedir. EBA içeriğinin ihtiyacı karşılamadığı sonucuna ulaşılmıştır. Hiçbir eğitim almayan ya da orta düzeyde eğitim alan katılımcıların, geliştirilmiş bir arayüze ve yapay zekâya sahip olan EBA Akademik Destek Platformu'nu etkili ve verimli kullanma konusunda yetersiz kalacakları düşünülmektedir. Araştırma sonucuna göre; okul yöneticileri tarafindan öğretmenlerin herhangi bir hizmet içi eğitime ya da kursa yönlendirilmediği, okuldaki görevli bilişim teknolojileri öğretmeni tarafından eğitim verildiği anlaşılmaktadır. Okulda verilen eğitimin bir tanıtımdan öteye gitmediği görülmüştür. Oysaki bu tür eğitimlerin bir plan kapsamında yapılması ve kişinin inisiyatifine bırakılmaması gerektiği düşünülmektedir.

Araştırmadan elde edilen başka bir sonuca göre, okul yöneticilerinin ve öğretmenlerin Akademik Destek Platformu'nu başarılı ve kullanışlı bulduğu söylenebilir. Elde edilen bu sonuç Varışoğlu (2019), Çakmak ve Taşkıran (2017), Bayyiğit-Teker (2019) tarafından yapılan araştırma sonuçları ile örtüşmektedir. Bununla birlikte platformun içerik olarak bazı eksikliklerinin olduğu, zenginleştirilmesi gerektiği sonucuna ulaşılmıştır. Saklan ve Ünal (2019), Saklan ve Ünal (2018) tarafından yapılan araştırmada öğretmenlerin dijital öğretim materyallerini yeterli görmedikleri ve EBA ile ilgili olarak yeterliliğin henüz beklenen düzeyde olmadığ1 sonucuna ulaşılmıştır. Elde edilen bu sonuç bu araştırmadan elde edilen sonucu desteklemektedir.

Araştırmadan elde edilen başka bir sonuca göre yönetici ve öğretmen arayüzünün sade ve kullanımının kolay olduğu sonucuna ulaşılmıştır. Bu sonuç; Tutar (2015), Çiftçi ve Aydın (2020) tarafından yapılan çalışmanın sonuçları ile örtüşmektedir. Platformda yer alan menü ve özelliklerin ise geliştirilmesi gerektiği sonucuna ulaşılmıştır. EBA Akademik Destek Platformu'nun yeni olduğu düşünüldüğünde, ifade edilen eksikliklerin normal olduğu ve hem okul yöneticilerinden hem de öğretmenlerden gelen talepler doğrultusunda zaman içerisinde bu eksiklerinin giderilebileceği söylenebilir. Bu araştırmanın da bu hususta geliştirme çalışmalarına katkıda bulunacağı düşünülmektedir.

Araştırma sonucuna göre yönetici ve öğretmenlerin büyük bir çoğunluğunun hedeflerinde herhangi bir değişikliğe gitmedikleri sonucuna ulaşılmıştır. Hedeflerinde değişiklik yapan okul yöneticisi ve öğretmenlerin ise basit düzeyde değişiklik yaptıkları sonucuna ulaşılmıştır. Elde edilen bu sonuç değerlendirildiğinde, EBA Akademik Destek Platformu'nun yeni olması nedeniyle okul yöneticileri ve öğretmenlerin hedeflerinde değişiklik yapmamalarının normal bir durum olduğu söylenebilir.

Araştırmadan elde edilen başka bir sonuca göre, okul yöneticilerinin EBA Akademik Destek Platformu'ndaki verileri ögretmenlerin performansını değerlendirmede kullanmadığ1 fakat ilerleyen zamanlarda bir kriter olarak kullanmayı düşündükleri sonucuna ulaşılmıştır. Bunun nedeni olarak EBA Akademik Destek Platformu'nun yeni olması ve öğretmenlerin platformu tam anlamı ile öğrenemediği ve kullanamadığı, bu yüzden de verilerin sağlıklı sonuçlar vermeyeceği ileri sürülebilir.

Araştırma sonucunda EBA Akademik Destek Platformu'nun öğretmenlerin iş yükünü artırdığı söylenmiş, öğretmenlerin genelde evde ekstra zaman ayırdıkları sonucuna ulaşılmıştır. Kuyubaşığlu ve Kılıç (2019), Kurtdede-Fidan, Erbasan ve Kolsuz (2016) tarafindan yapılan araştırma sonuçlarına göre, öğretmenlerin EBA kullanımına ilişkin yüksek düzeyde katımlarının olduğu, EBA sayesinde öğretmenlerin bilgiye kolay erişebildikleri, öğrenmeyi kolaylaştırdığı, öğretmenin yeni araç gereci olduğu ve EBA ile derslerin daha zevkli geçtiği, EBA'nın öğretmen 
motivasyonuna etkisi olduğu ve EBA'nın farklı öğrenme stillerindeki öğrencilere hitap ettiği sonucuna ulaşmışlardır. Bu sonuç araştırmadan elde edilen sonuç ile örtüşmemektedir.

Elde edilen başka bir sonuca göre; EBA Akademik Destek Platformu'nda yer alan içeriklerin, öğretim programında yer alan kazanımlarla uyumlu ve uygulanabilir olduğu tespit edilmiştir.

Araştırma sonucunda EBA Akademik Destek Platformu'nun olumsuz yönleri olarak; makineleşmiş, duygusuz, hedeflerinden kopuk ve bağımlı dijital bir nesil yetişmesine sebep olabileceği, sistemsel sıkıntılardan dolayı bazı zamanlar kullanılamadığı, branşlara ait içeriklerin yetersiz olduğu ve geliştirilmesi gerektiği ve öğretmenler tarafından yükleme yapılan bölümün yetersiz olduğu sonucuna ulaşılmıştır. Akademik Destek Platformu'nun olumlu yönleri olarak; yapılan işlemler ile ilgili hızlı ve kaliteli dönütler verdiği, gelişmiş ve kaliteli rehberlik hizmeti sunduğu, eğitim-öğretimin istenilen yerde ve zamanda yapılmasını sağladığı, raporlama hizmeti ile yönetici ve öğretmenlerin eğitim sürecini ve öğrenciyi daha iyi takip edebilmelerini sağladığı, öğretmenlere eğitim-öğretim sürecinde destek sağladığı ve kaliteli, kalıcı öğrenme sağlayan bir uzaktan eğitim platformu olduğu sonucuna ulaşılmıştır. Ayrıca katılımcılar; içerik olarak geliştirilmesi, yönetici arayüzü raporlarının genişletilmesi ve geliştirilmesi ve sistemsel sorunların giderilmesi gerektiğini önermişlerdir. Literatürde yapılan çalışmalar incelendiğinde, (Demircioğlu ve Yadiğaroğlu, 2014; Dursun, Kırbaş ve Yüksel, 2015; Eren ve Avc1, 2016) genel olarak EBA içeriklerinin zenginleştirilmesi gerektiği sonucuna ulaşılmıştır. Ayrıca Çakmak ve Taşkıran (2017) yaptıkları araştırmada öğretmenlerin, EBA'nın içeriği zenginleştirilirse, okullara gerekli internet alt yapısı sağlanırsa ve öğretmen-öğrenci ve veli iş birliği sağlanırsa EBA platformunun daha faydalı olacağını düşündükleri sonucuna ulaşmışlardır. Araştırma sonuçlarına dayalı olarak aşağıdaki öneriler sunulmaktadır.

EBA Akademik Destek Platformu'nu kullanmayı ekstra iş yükü olarak gören öğretmenlere yönelik yönlendirici, özendirici ve destekleyici tanıtımlar ve hizmet içi eğitimler düzenlenebilir.

$\checkmark$ Süreç içinde EBA Akademik Destek Platformu'na eklenen özellikler ile ilgili okul bünyesinde gerekli tanıtımlar yapılarak eğitimler verilebilir.

$\checkmark$ EBA Akademik Destek Platformu içerik olarak geliştirilebilir ve eksik olan temel branşlardan İngilizce en kısa zamanda sisteme eklenebilir.

$\checkmark$ EBA Akademik Destek Platformu yapılacak ihtiyaç analizleri doğrultusunda arayüz, menü ve özellikler bakımından geliştirilebilir.

$\checkmark$ Sistemsel arızaların önüne geçilmesi için Milli Eğitim Bakanlığı tarafından gerekli donanımsal tedbirler alınabilir.

$\checkmark$ Öğretmen Performans Değerlendirme kriteri olarak EBA Akademik Destek verileri kullanılabilir. Bu doğrultuda yönetmeliklerde gerekli düzenlemeler yapılabilir.

Araştırmacılara yönelik öneriler:

$\checkmark$ EBA Akademik Destek Platformu ile ilgili veli ve öğrenci görüşleri araştırılabilir.

$\checkmark$ EBA Akademik Destek Platformu'nda yer alan içerikler ile ilgili branş bazlı araştırmalar yapılabilir.

$\checkmark$ EBA Akademik Destek Platformu'nun belirli değişkenlere (cinsiyet, mesleki kıdem, branş vb.) bağlı olarak öğretmen kullanım oranları araştırılabilir.

$\checkmark$ EBA Akademik Destek Platformu'nun öğrenci başarısına etkisi araştırılabilir. 


\section{Kaynakça}

Akyürek, H.A. (2013). Yapay zekâ teknikleri kullanarak akıllı iş gücü yönetimi (Yayımlanmamış yüksek lisans tezi). Mevlana Üniversitesi, Konya.

Akyürek, M.İ. (2020). Uzaktan eğitim: Bir alanyazın taraması. Medeniyet Eğitim Araşstırmaları Dergisi, 4(1), 1-9.

Alabay, A. ve Taşdelen, V. (2017). Ortaöğretim öğretmenlerinin ve öğrencilerinin EBA (Eğitimde Bilişim Ağı) kullanımına ilişkin görüşleri üzerine bir araştırma. İstanbul Aydın Üniversitesi Eğitim Fakültesi Dergisi, Özel Sayl, 27-29.

Altın, H.M. ve Kalelioğlu, F. (2015). FATİH Projesi ile ilgili öğrenci ve öğretmen görüşleri. Başkent University Journal of Education, 2(1), 89-105.

Aslan, A.A. (2019). Müze eğitiminde yapay zekanın kullanılması (Yayımlanmamış yüksek lisans tezi). Ankara Üniversitesi, Ankara.

Bahçeci, F. ve Efe, B. (2018). Lise öğrencilerinin Eğitim Bilişim Ağı (EBA) sitesine yönelik görüşlerinin değerlendirilmesi. Kuramsal Eğitimbilim Dergisi, 11(4), 676-692. doi: 10.30831/akukeg.387055

Bayyiğit-Teker, Ş. (2019). Öğretmenlerin teknolojik pedagojik alan bilgisi (TPAB) yeterlilikleri ile eğitim biliş̧im ăğ (EBA) kullanımına yönelik tutumları arasındaki ilişki (Yayımlanmamış yüksek lisans tezi). Balıkesir Üniversitesi, Balıkesir.

Bergdahl, N. ve Nouri, J. (2020). Covid-19 and crisis-prompted distance education in Sweden. Technology, Knowledge and Learning, 1-17. doi:10.1007/s10758-020-09470-6

Christensen, L.B., Johnson, B. ve Turner, L.A. (2011). Research methods, design, and analysis. New York: Pearson Education.

Coşkunserçe, O. ve İşçitürk, G.B. (2019). Eğitim Bilişim Ağı (EBA) Platformu hakkında öğrencilerin farkındalığının artırılmasına yönelik bir durum çalışması. Eğitimde Nitel Araştırmalar Dergisi, 7(1), 260-276. doi:10.14689/issn.2148-2624.1.7c1s.12m

Çakmak, Z. ve Taşkıran, C. (2017). Sosyal bilgiler öğretmenlerinin perspektifinden Eğitim Bilişim Ağı (EBA) platformu. Uluslararası Türk Ĕ̆itim Bilimleri Dergisi, 9, 284-295.

Çiftçi, B. ve Aydın, A. (2020). Eğitim Bilişim Ağı (EBA) Platformu hakkında fen bilimleri öğretmenlerinin görüşleri. Türkiye Kimya Derneği Dergisi Kısım C: Kimya Eğitimi, 5(2), 111-130. doi:10.37995/jotcsc.765647

Demircioğlu, G. ve Yadiğaroğlu, M. (2014). Kimya öğretmenlerinin FATíH Projesine ilişkin görüşleri. Ĕgitim ve Öğretim Araştırmaları Dergisi, 3(2), 302-310.

Dursun, A., Kırbaş, İ. ve Yüksel, M.E. (2015). Fırsatları Artırma ve Teknolojiyi İyileştirme Hareketi (FATIH) projesi ve proje üzerine bir değerlendirme. İnet-Tr'15, XX. Türkiye'de İnternet Konferans1, İstanbul Üniversitesi, İstanbul.

Eğitim Bilişim Ağı. (2020). Akademik Destek kullanım kılavuzu. https://www.eba.gov.tr/yardim-sss/assets/pdf/ADES_Kullanim_Kilavuzu.pdf (Erişim tarihi: 26.04.2020).

Eren, E. ve Avcı, Z.Y. (2016). Okul-üniversite işbirliği kapsamında e-içeriklerin geliştirilmesi: Teknoloji entegrasyonu planlama modeli kapsamında bir durum değerlendirmesi. Uşak Üniversitesi Sosyal Bilimler Dergisi, 9(2), 210-234.

Esdeira, F.A.A. (2017). Bilgi yönetimi için anlamsal öğrenme ortamlarının incelenmesi (Yayımlanmamış yüksek lisans tezi). Kastamonu Üniversitesi, Kastamonu. 
Jacobs, G.M. ve Ivone, F.M. (2020). Infusing cooperative learning in distance education. TESLEJ, 24(1), 1-15.

Karasu, T. (2018). İmam Hatip Meslek ve DİKAB dersi öğretmenlerinin Eğitim Bilişim Ağ (EBA) ile ilgili görüşleri. Bitlis Eren Üniversitesi Sosyal Bilimler Enstitüsü Dergisi, 7(2), 925-943.

Kayabaş, İ. (2010). Yapay zeka sohbet ajanlarının uzaktan eğitimde öğrenci destek sistemi olarak kullanılabilirliği (Yayımlanmamış yüksek lisans tezi). Anadolu Üniversitesi, Eskişehir.

Kurtdede-Fidan, N., Erbasan, Ö. ve Kolsuz, S. (2016). Sınıf öğretmenlerinin Eğitim Bilişim Ağı'ndan (EBA) yararlanmaya ilişkin görüşleri. Journal of International Social Research, 9(45), 626-637.

Kuyubaşıoğlu, R.M. ve Kılıç, F. (2019). Ortaokul öğretmenlerinin görüşlerine göre EBA (Eğitimde Bilişim Ağı) kullanım düzeylerinin incelenmesi. İleri Eğitim Çalışmaları Dergisi (Journal of Advanced Education Studies), 1(1), 32-52.

McMillan, J.H. ve Schumacher, S. (2006). Research in education: Evidence-based inquiry. Boston: Allyn and Bacon Inc.

Memişoğlu, B. ve Tapan-Broutin, S.M. (2018). FATİH Projesi bileşenlerinin eTwinning projesine entegrasyonu. Gür, H. ve Şahan, H. H. (Ed.), Uluslararası Necatibey Eğitim ve Sosyal Bilimler Araştırmaları Kongresi (UNESAK 2018) Bildiri Tam Metin Kitabı içinde (ss. 136-147). Ankara.

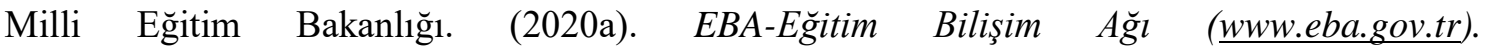
http://fatihprojesi.meb.gov.tr/icerik.html (Erişim tarihi: 24.04.2020).

Milli Eğitim Bakanlığı. (2020b). FATIH Projesi hakkında. http://fatihprojesi.meb.gov.tr/about.html (Erişim tarihi: 24.04.2020).

Noe, R. (2009). İnsan kaynaklarının eğitim ve gelişstirilmesi (C. Çetin, Çev.). İstanbul: Propedia Yayıncilik.

Özalpman, D. (2010). Bir temellendirilmiş kuram denemesi: Politik amaçla marka seçen tüketici yönetimi. İstanbul Üniversitesi İletişim Fakültesi Dergisi (Istanbul University Faculty of Communication Journal), 1(39), 119-135.

Özarslan, Y. ve Ozan, Ö. (2014). Yükseköğretimde uzaktan eğitim programı açma sorunsalı. XIX. Türkiye'de İnternet Konferans1, Yaşar Üniversitesi, İzmir.

Özbay, Ö. (2015). Dünyada ve Türkiye'de uzaktan eğitimin güncel durumu. Uluslararası Ë̆itim Bilimleri Dergisi, 2(5), 376-394.

Özen, E. (2019). Eğitimde dijital dönüşüm ve Eğitim Bilişim Ağ1 (EBA)(editöre mektup). Açıö̈gretim Uygulamaları ve Araştırmaları Dergisi, 5(1), 5-9.

Özsoy, S. ve Çetinkaya, A. (2014). Nitel araştırma desenlerinden gömülü kuram (Grounded Theory). Ege Üniversitesi Hemşirelik Fakültesi Dergisi, 30(1), 153-164.

Öztuna, B. (2017). Endüstri 4.0 (dördüncü sanayi devrimi) ile çalışma yaşamının geleceği. Ankara: Gece Kitaplığı.

Patton, M.Q. (2005). Qualitative research. John Wiley \& Sons, Ltd. doi:10.1002/0470013192.bsa514

Romero Martínez, S.J., Ordóñez Camacho, X.G., Guillén-Gamez, F.D. ve Bravo Agapito, J. (2020). Attitudes toward Technology among Distance Education Students: Validation of an Explanatory Model. Online Learning, 24(2), 59-75. doi:10.24059/olj.v24i2.2028 
Saklan, H. ve Ünal, C. (2018). Teknoloji dostu fen bilimleri öğretmenlerinin Eğitim Bilişim Ağ (EBA) hakkındaki görüssleri. Necatibey Eğitim Fakültesi Elektronik Fen ve Matematik Eğitimi Dergisi, 12(1), 493-526. doi:10.17522/balikesirnef.437847

Saklan, H. ve Ünal, C. (2019). Dijital eğitim platformları arasında EBA'nın yeri ile ilgili fen bilimleri öğretmenlerinin görüşleri. On dokuz Mayıs Üniversitesi Ĕgitim Fakültesi Dergisi, 38(1), 19-34. doi:10.7822/omuefd.431247

Saldana, J. (2015). The coding manual for qualitative researchers. London: Sage.

Sleeman, D. ve Brown, J.S. (Ed.). (1982). Introduction: Intelligent tutoring systems. In intelligent tutoring systems (ss.1-11). Orlando, FL: Academic Press.

Sözen, N. (2020). COVID 19 sürecinde uzaktan eğitim uygulamaları üzerine bir inceleme. Avrasya Sosyal ve Ekonomi Araştırmaları Dergisi, 7(12), 302-319.

Strauss, A. ve Corbin, J. (1990). Basics of qualitative research (Vol. 15). Newbury Park, CA: Sage Publications.

Strauss, A. ve Corbin, J. (1998). Basics of Qualitative Research: Techniques and Procedures for Developing Grounded Theory. California: Sage publications.

Şahin, M. ve Erman, E. (2019). Tarih dersi öğretmenlerinin Eğitim Bilişim Ağı'na (EBA) ilişkin görüşlerinin incelenmesi. Mehmet Akif Ersoy Üniversitesi Eğitim Fakültesi Dergisi,49, 256-275. doi:10.21764/maeuefd.425608

The Organisation for Economic Co-Operation and Development (OECD). (2020). Development co-operation report 2020. https://www.oecd.org/development/development-co-operationreport-20747721.htm (Erişim Tarihi: 10.04.2021)

Tutar, M. (2015). Eğitim bilişsim ă̆ı (EBA) sitesine yönelik olarak öğretmenlerin görüşlerinin değerlendirilmesi (Yayımlanmamış Yüksek lisans tezi). Karadeniz Teknik Üniversitesi, Trabzon.

United Nations Educational, Scientific and Cultural Organization (UNESCO). (2021). School closures caused by Coronavirus(Covid-19). https://en.unesco.org/covid19/educationresponse (Erişim Tarihi: 11.04.2021)

Uşun, S. (2006). Uzaktan eğitim. Ankara: Nobel Yayınları.

Varışoğlu, B. (2019). Öğretmenlerin Eğitim Bilişim Ağı (EBA) tutumlarının incelenmesi. Turkish Studies - Social Sciences, 14(6), 3511-3521. doi:10.29228/TurkishStudies.39294

Yenilik ve Eğitim Teknolojileri Genel Müdürlügü. (2020) . Eğitim Bilişim Ağg'nın (EBA) yeni dönem lansmanı gerçekleşti. https://yegitek.meb.gov.tr/www/egitim-bilisim-aginin-eba-yenidonem-lansmani-gerceklesti/icerik/2999 (Erişim tarihi: 25.04.2020).

Yenilik ve Eğitim Teknolojileri Genel Müdürlüğü. (2020). 12. Sinıf ögrrencilerine EBA'dan Akademik Destek. https://yegitek.meb.gov.tr/www/11-ve-12-sinif-ogrencilerine-ebadanakademik-destek/icerik/3014 (Erişim tarihi: 25.04.2020)

Yıldırım, A. ve Şimşek, H. (2006). Sosyal bilimlerde nitel araştırma yöntemleri. Ankara: Seçkin Yayıncilik.

Yıldırım, A. ve Şimşek, H. (2008). Sosyal bilimlerde nitel araştırma yöntemleri. Ankara: Nobel Yayınları.

Yıldırım, A. ve Şimşek, H. (2011). Sosyal bilimlerde nitel araştırma yöntemleri. Ankara: Seçkin Yayıncilik. 
Yılmaz, S. (2011). İlköğretim dördüncü sınıf öğrencilerinin "Birlikte Çalışma” ya ilişkin algıları. Ahi Evran Üniversitesi Eğitim Fakültesi Dergisi, 12(1), 1-14.

Yılmaz, Z.A. (2020). Fen bilimleri öğretmenlerinin FATİH Projesi ve akıllı tahta hakkındaki görüşleri. Uluslararası Ĕ̌itim Araştırmacıları Dergisi, 3(1), 71-83.

\section{ETİK ve BİLIMSEL İLKELER SORUMLULUK BEYANI}

$\mathrm{Bu}$ çalışmanın tüm hazırlanma süreçlerinde etik kurallara ve bilimsel atıf gösterme ilkelerine riayet edildiğini yazarlar beyan eder. Aksi bir durumun tespiti halinde Afyon Kocatepe Üniversitesi Sosyal Bilimler Dergisi'nin hiçbir sorumluluğu olmayıp, tüm sorumluluk makale yazarlarına aittir. Yazarlar etik kurul izni gerektiren çalışmalarda, izinle ilgili bilgileri (kurul adı, tarih ve sayı no)yöntem bölümünde ve ayrıca burada belirtmişlerdir.

Kurul adı: Erzincan Binali Yıldırım Üniversitesi İnsan Araştırmaları Etik Kurulu

Tarih: 29/08/2020

No: $05 / 18$

\section{ARAŞTIRMACILARIN MAKALEYE KATKI ORANI BEYANI}

1. yazar katk1 oranı : $\% 50$

2. yazar katk1 oranı : $\% 50$ 